\title{
Comparative effects of prolonged freshwater and saline flooding on nitrogen cycling in an agricultural soil
}

Sanchez Rodriguez, Antonio; Chadwick, David; Tatton, Gemma; Hill, Paul; Jones, Davey L.

\section{Applied Soil Ecology}

DOI:

10.1016/j.apsoil.2017.11.022

Published: 01/04/2018

Peer reviewed version

Cyswllt i'r cyhoeddiad / Link to publication

Dyfyniad o'r fersiwn a gyhoeddwyd / Citation for published version (APA):

Sanchez Rodriguez, A., Chadwick, D., Tatton, G., Hill, P., \& Jones, D. L. (2018). Comparative effects of prolonged freshwater and saline flooding on nitrogen cycling in an agricultural soil. Applied Soil Ecology, 125, 56-70. https://doi.org/10.1016/j.apsoil.2017.11.022

\footnotetext{
Hawliau Cyffredinol / General rights

Copyright and moral rights for the publications made accessible in the public portal are retained by the authors and/or other copyright owners and it is a condition of accessing publications that users recognise and abide by the legal requirements associated with these rights.

- Users may download and print one copy of any publication from the public portal for the purpose of private study or research.

- You may not further distribute the material or use it for any profit-making activity or commercial gain

- You may freely distribute the URL identifying the publication in the public portal ?
}

Take down policy

If you believe that this document breaches copyright please contact us providing details, and we will remove access to the work immediately and investigate your claim. 
1 Comparative effects of prolonged freshwater and saline flooding on nitrogen cycling in

\section{2 an agricultural soil}

3 Antonio Rafael Sánchez-Rodríguez*, David R. Chadwick, Gemma S. Tatton, Paul W. Hill,

$4 \quad$ Davey L. Jones

5 School of the Environment, Natural Resources and Geography, College of Natural Sciences,

6 Bangor University, Gwynedd LL57 2UW, UK

$7 \quad$ *Corresponding author: afs42a@ bangor.ac.uk

8 Tel.: +44 1248 383052; fax: +44 1248 354997. (A.R. Sánchez-Rodríguez). 


\section{Abstract}

Due to climate change, the frequency and duration of flood events are predicted to increase in many regions of the world. This is expected to cause large changes in soil functioning and to a progressive decline in soil quality such as reduced rates of nutrient cycling, enhanced greenhouse gas emissions and loss of soil biodiversity. There is a knowledge gap, however, on how temperate agricultural soils under different management practices (e.g. manure application) respond to prolonged river or coastal flooding. The main objective of this work was to determine the effects of a simulated prolonged flooding with saline and freshwater on soil $\mathrm{N}$ cycling, following application of a low $\mathrm{C}: \mathrm{N}$ organic amendment (broiler litter) at two temperatures, representative of a winter and a spring flood event. Using laboratory mesocosms we simulated prolonged winter $\left(6^{\circ} \mathrm{C}\right)$ and spring $\left(14^{\circ} \mathrm{C}\right)$ flooding of soil amended with broiler litter. We also compared the effects of inundation with either river (freshwater) or coastal (saline) water. An agricultural grassland soil (Eutric Cambisol) was subjected to different combinations of treatments (flood with fresh or saline water, winter vs spring temperatures, with/without poultry manure). The impact of these treatments on soil solution $\mathrm{N}$ dynamics, greenhouse gas emissions $\left(\mathrm{CO}_{2}, \mathrm{CH}_{4}, \mathrm{~N}_{2} \mathrm{O}\right)$ and microbial community structure (by PLFA analysis) were evaluated over an 11 week simulated flood event followed by an 8 week soil recovery period (without flood). Overall, potential losses of $\mathrm{NH}_{4}{ }^{+}$and cumulative GHG emissions were increased by flooding and the presence of manure. $\mathrm{CH}_{4}$ emissions were found to dominate under freshwater flooding conditions and $\mathrm{N}_{2} \mathrm{O}$ under saline flooding. Significant releases of GHG occurred during both flooding and after floodwater removal. Temperature was less influential on regulating GHG under the different treatments. These releases in GHG were associated with disruption in $\mathrm{N}$ cycling and changes in soil microbial composition and these changes persisted after floodwater removal. Extreme flooding negatively impacts soil functioning, however, the magnitude of any changes remain critically dependent on flood 
duration and source of flood water, and management conditions. Further work is required at the field scale to understand the molecular basis of the responses observed in this study.

\section{Highlights}

- $\mathrm{NH}_{4}{ }^{+}$losses and GHG emissions were increased by flooding in the presence of manure.

- $\mathrm{CH}_{4}$ is mostly emitted in freshwater flooding and $\mathrm{N}_{2} \mathrm{O}$ in saline flooding.

- Temperature was less important in regulating GHG emissions but did affect $\mathrm{N}$ cycling under flooding.

- Flooding induces prolonged shifts in the composition of the soil microbial community.

- Extreme flooding events negatively impact soil functioning.

Keywords: Soil quality, Phospholipid fatty acid analysis, Soil microbial biomass, Extreme weather event; Waterlogging

Abbreviations: GHG, greenhouse gas; PLFA, phospholipid fatty acid.

\section{Funding}

This work was supported by the Project 'Legacy effects of the extreme flood events on soil quality and ecosystem functioning', NERC Grant Reference NE/M005143/1, and by the UK Department for Environment, Food and Rural Affairs (DEFRA) project LM0316, and Sêr Cymru LCEE-NRN project, Climate-Smart Grass. Sánchez-Rodríguez also acknowledges funding support by the 'Fundación Ramón Areces' for his postdoctoral scholarship “Beca para ampliación de estudios en el extranjero en materia de Ciencias de la Vida y de la Materia". 


\section{Introduction}

Changes in global weather patterns and the increased incidence of extreme events in recent years are starting to negatively impact on the sustainability of agricultural ecosystems (IPCC, 2013). Although storms and extreme flood events are not rare, evidence suggests that their frequency and magnitude is increasing in many regions of the world (Pohl et al., 2017; WMO, 2013). These are exemplified by recent extreme flood events in many parts of Europe (Met Office, 2014; Romanescu and Stoleriu, 2017). Typically, these are triggered by prolonged heavy rainfall, however, they are being further compounded in coastal regions by global sea level rise and tidal surges (Haigh et al., 2016; Nicholls et al., 1999). In some cases, flooding affects soils with a known history of waterlogging (e.g. Fluvisols, Gleysols) and the consequences may not be too severe, however, areas with no previous history of flooding are also becoming affected. For example, in the extreme winter storms of 2014, floodwater covered large areas of agricultural land in the UK for up to 3 months with floodwater depths exceeding $2 \mathrm{~m}$, ultimately leading to the loss of crops and excessive soil erosion (Defra, 2014; Sibley et al., 2015; Smith et al., 2017). These extreme events have the potential to cause irreversible damage to plant growth, agricultural productivity and ecosystem functioning (Niu et al., 2014), as a result of disruptions in soil physical structure, nutrient cycling (Baldwin and Mitchell, 2000; Scalenghe et al., 2012) and soil microbial function (Bossio and Scow, 1998). plant $\mathrm{N}$ uptake (Herzog et al., 2016). Typically, prolonged waterlogging can cause the accumulation of $\mathrm{NH}_{4}{ }^{+}$in soil (White and Reddy, 2009), stimulate $\mathrm{NH}_{3}$ volatilization (ZhongCheng et al., 2012), whilst any $\mathrm{NO}_{3}{ }^{-}$present in the soil at the time of flooding may be 
flooding also has the potential to increase leaching of residual soil nitrate depending on the nature of the flood event (i.e. surface- versus ground-water driven floods; Huber et al., 2012). The relative contribution of different anthropogenic activities to the increased incidence of flooding remains uncertain, however, it has been directly linked to shifts in land use, increased urban run-off, river network engineering and indirectly to increased greenhouse gas (GHG) emissions (i.e., methane- $\mathrm{CH}_{4}$, carbon dioxide- $\mathrm{CO}_{2}$ and nitrous oxide- $\mathrm{N}_{2} \mathrm{O}$ ) (Pall et al., 2011). As the agricultural release of $\mathrm{CH}_{4}$ and $\mathrm{N}_{2} \mathrm{O}$ are frequently stimulated under waterlogging conditions, there is potential for a positive feedback on climate change and flood risk. In addition, $\mathrm{N}_{2} \mathrm{O}$ may be released following floodwater removal as the block in nitrification is removed or during partial denitrification (Norton, 2008; Robertson and Groffman, 2007).

There are numerous studies on the effects of flooding on $\mathrm{N}$ and carbon (C) cycling in rice paddy fields (Nguyen et al., 2015; Peng et al., 2011; Pereida et al., 2013; Zhang et al., 2012; Zhang et al., 2015), riparian zones (Baldwin and Mitchell, 2000) and wetlands (Unger et al., 2009; Wang et al., 2013). In contrast, however, there are fewer published studies on the impacts of extreme flooding for temperate agricultural soils, particularly those with no previous history of flooding and under contrasting management regimes (Hansen et al., 2014).

We hypothesize that one of the agricultural practices that is most likely to influence how soil quality responds to flooding is the presence of nutrient-rich organic material with different $\mathrm{N}$ mineralization rates (e.g. animal manures or green cover crops; Masunga et al., 2016). Our rationale is that these fertilisers are typically applied to soil before crop establishment when winter/spring flooding occurs and they are well known to promote shifts in microbial community functioning and greatly influence net GHG emissions (Snyder et al., 2009). Further, we hypothesized that the outcome will be greatly influenced by floodwater type. We predict that saline coastal flooding will emit less GHG due to the high concentration of alternative electron acceptors in seawater $\left(28 \mathrm{mM} \mathrm{SO}_{4}{ }^{2-}\right)$ relative to freshwater (ca. $<0.1$ 
$\mathrm{mM} \mathrm{SO}_{4}{ }^{2-}$ ), and also to the negative impact of excess $\mathrm{NaCl}$ on microbial activity. Our aim was therefore to determine the effects of simulated prolonged flooding with saline or freshwater on soil $\mathrm{N}$ cycling, following the application of a low $\mathrm{C}: \mathrm{N}$ organic amendment (broiler litter), which could accelerate or slow the decomposition of soil organic matter (Liu et al., 2017) at two temperatures, representative of a winter and a spring flood. Our main objectives were to investigate alterations in (1) $\mathrm{N}$ cycling, including changes in soil water chemistry and GHG emissions $\left(\mathrm{CH}_{4}, \mathrm{CO}_{2}\right.$ and $\left.\mathrm{N}_{2} \mathrm{O}\right)$, and (2) soil microbial structure at the end of flooding (11 weeks), and after the soil recovery period (8 weeks).

\section{Materials and methods}

\subsection{Soil, water and manure properties}

Replicate soil samples (5-20 cm depth; Ah horizon, Eutric Cambisol) were collected from a low intensity sheep (Ovis aries L.) grazed grassland dominated by Lolium perenne L. located at the Henfaes Experimental Station, Abergwyngregyn, UK (5314'19"N, $4^{\circ} 00^{\prime} 55^{\prime \prime} \mathrm{W}$; altitude $18 \mathrm{~m}$ a.s.1.). The mean annual temperature at the site is $10^{\circ} \mathrm{C}$ and the mean annual rainfall is $960 \mathrm{~mm}$. Within living memory, the sampling site has not previously been flooded, however, the surrounding region has recently been subjected to both unprecedented river and coastal flooding (Sibley et al., 2015; see Supplementary Information, Fig. A.1 and Fig. A.2). Prior to use, the soil was coarse-sieved $(1 \mathrm{~cm}$ mesh) to remove any discernible roots and stones, maintain the soil's crumb structure and minimize changes in microbial activity and $\mathrm{N}$ cycling (Jones and Willett, 2006). Particle size was analyzed according to Gee and Bauder (1986) while total $\mathrm{C}$ and $\mathrm{N}$ was determined using a Truspec ${ }^{\circledR} \mathrm{CN}$ Elemental Analyser (Leco Corp, St Joseph, MI). Plant-available $\mathrm{P}$ and $\mathrm{K}$ were determined by extracting the soil with $0.5 \mathrm{M}$ acetic acid (1:5 $\left.\mathrm{w} / \mathrm{v} ; 1 \mathrm{~h}, 200 \mathrm{rev} \mathrm{min}^{-1}\right)$, centrifuging the extracts $(10,000 \mathrm{~g}, 10 \mathrm{~min})$ and analyzing $\mathrm{P}$ by the molybdate blue method of Murphy and Riley (1962) and K by flame photometry using a 
Sherwood Scientific Flame Photometer (Fisher Scientific, Loughborough, UK). Soil pH and electrical conductivity (EC) were determined in $(1: 2.5 \mathrm{v} / \mathrm{v})$ soil:distilled water extracts using standard electrodes.

Two different sources of floodwater were used in the experiment: (1) freshwater from the nearest large watercourse (Rhaeadr-fawr river, $53^{\circ} 14^{\prime} 8^{\prime \prime} \mathrm{N}, 4^{\circ} 0^{\prime} 59^{\prime \prime} \mathrm{W}$; located ca. $350 \mathrm{~m}$ away from the soil sampling site), and (2) seawater, from the adjacent Menai Strait $\left(53^{\circ} 14^{\prime}\right.$ $20^{\prime \prime} \mathrm{N}, 4^{\circ} 14^{\prime \prime} \mathrm{W}$; located ca. $700 \mathrm{~m}$ away from the soil sampling site). Floodwater $\mathrm{pH}$ and EC were measured directly using standard electrodes, while $\mathrm{NH}_{4}{ }^{+}$was determined colorimetrically using the salicylate method of Mulvaney (1996) and $\mathrm{NO}_{3}{ }^{-}$using the vanadate method of Miranda et al. (2001) using an Epoch ${ }^{\circledR}$ microplate spectrophotometer (BioTek Instruments Inc., Winooski, VT).

Broiler litter was collected from a commercial poultry farm on Anglesey, North Wales $\left(53^{\circ} 15^{\prime} \mathrm{N}, 4^{\circ} 18^{\prime} \mathrm{W}\right)$. Its dry matter content was determined by oven drying $\left(105^{\circ} \mathrm{C}, 48 \mathrm{~h}\right)$. Its total $\mathrm{C}$ and $\mathrm{N}$ content, $\mathrm{NH}_{4}{ }^{+}$and $\mathrm{NO}_{3}{ }^{-}$were determined on fresh material as detailed above. Total $\mathrm{P}$ and total $\mathrm{K}$ were analysed in dry manure $\left(105^{\circ} \mathrm{C}, 24 \mathrm{~h}\right)$ after sieving to pass a $1 \mathrm{~mm}$ screen and digesting with aqua-regia (EPA, 2016). Manure $\mathrm{pH}$ was determined in a 1:6 (w/v) manure:distilled water extract using standard electrodes while uric acid was determined according to Cox et al. (1996). After collection, all soil, floodwater and manure were kept refrigerated at $4{ }^{\circ} \mathrm{C}$ until required.

\subsection{Experimental treatments and stages of the experiment}

Transparent polypropylene containers $(11 \times 8 \mathrm{~cm}$ base, $27 \mathrm{~cm}$ high; $n=48)$ were filled with $850 \mathrm{~g}$ of sieved field-moist soil to achieve a bulk density of $1 \mathrm{~g} \mathrm{~cm}^{-3}$ based on field measurements of the soil in situ. Broiler litter $\left(8 \mathrm{~g} \mathrm{mesocosm}^{-1}\right.$, equivalent to $9.1 \mathrm{t} \mathrm{ha}^{-1}$ on a surface area basis) was then mixed by hand with the soil in half of the mesocosms. The rate 
was chosen to reflect those typically used on UK grasslands (Defra, 2010). Broiler litter was chosen based on its widespread use for improving soil quality and its presence in fields impacted by the UK's 2014 extreme floods. Overall, the experiment had 4 main treatments:

1. Soil only (Control)

2. Soil + flooding

3. Soil + manure

4. Soil + manure + flooding

The secondary factors in the experiment were floodwater type (freshwater vs. saline) and temperature regime $\left(6{ }^{\circ} \mathrm{C}\right.$ vs. $\left.14^{\circ} \mathrm{C}\right)$ giving 48 mesocosms in total. A Rhizon ${ }^{\circledR}$ soil water sampler (Rhizosphere Research Products, Wageningen, The Netherlands) was placed in the centre of the soil at an angle of $45^{\circ}$ in each mesocosm prior to the addition of floodwater. Two hundred and fifty $\mathrm{ml}$ of fresh or saline floodwater was carefully added to the soil surface in all mesocosms to achieve field capacity - these were defined as the non-flooded treatments. For the 'flooded' treatments, additional floodwater (ca. 1 1) was added to half the mesocosms to achieve a flood depth $9 \mathrm{~cm}$ above the soil surface. This reflected field observations of typical flood depths within the region. Finally, the boxes were randomized and placed in climatecontrol rooms in the dark at either $6{ }^{\circ} \mathrm{C}$ (simulated winter) or $14{ }^{\circ} \mathrm{C}$ (simulated spring) and loosely covered with polythene to minimize evaporative losses. In total, there were 16 combinations of factors, with each treatment performed in triplicate.

The experiment had two different stages: (1) the flood stage (0-11 weeks) in which half the mesocosms were kept flooded; and (2) the recovery stage (12-20 weeks), in which the standing water was removed from the flooded treatments. The unflooded mesocosms were maintained at field capacity for the first 14 weeks by adding distilled water weekly (based on their weight loss). Similarly, the flood depth was maintained at a constant height during the flood phase by weekly additions of floodwater. No water was added to the mesocosms in weeks 
15 to 20 to allow the soil to dry (reflecting typical field conditions in late spring). During this latter period soil solutions were not collected as the soil was too dry.

\subsection{Flood and soil water chemistry}

Weekly sampling of floodwater and soil solution were made for the first 14 weeks using a pipette and the Rhizon ${ }^{\circledR}$ samplers, respectively, and analysed for $\mathrm{NH}_{4}{ }^{+}$and $\mathrm{NO}_{3}{ }^{-}$as described above. $\mathrm{pH}$ and $\mathrm{EC}$ in the floodwater were measured on the first and last day of the flood stage.

During the flood stage, the potential losses of nutrients or the total amount of nutrient released into the soil solution and overlying floodwater $\left(C_{\text {release }}\right)$ was calculated as follows:

$$
C_{\text {release }}\left(\text { g container }^{-1}\right)=\left[C_{\text {sol }} \times V_{\text {soil }} \times \Theta\right]+\left[C_{\text {flood }} \times V_{\text {flood }}\right]
$$

where $C_{\text {sol }}$ is the concentration of nutrient in the soil solution, $C_{\text {flood }}$ is the concentration in the floodwater (the maximum concentrations obtained in the flood phase), $V_{\text {soil }}$ and $V_{\text {flood }}$ are the volume of soil and floodwater respectively and $\Theta$ is the volumetric water content $\left(0.5 \mathrm{~cm} \mathrm{~cm}^{-3}\right)$.

\subsection{Greenhouse gas measurements}

For the GHG measurements, the containers were hermetically sealed and two $20 \mathrm{ml}$ gas samples taken from the container headspace through a rubber septum, the first one at time 0 $\left(\mathrm{T}_{0}\right)$ and the second one after $60 \mathrm{~min}\left(\mathrm{~T}_{60}\right)$. GHG sampling occurred 3-4 times per week at the beginning and at the end of the flood stage, and at the beginning of soil recovery stage, but was reduced to once per week for the other periods of the experiment. Pre-evacuated glass vials were used to store headspace samples prior to analysis. Methane, $\mathrm{CO}_{2}$ and $\mathrm{N}_{2} \mathrm{O}$ concentrations in the headspace of the mesocosms were analysed using a Clarus 500 gas chromatograph equipped with a capillary column and Turbomatrix HS-40 headspace autoanalyzer (carrier gas pressure $138 \mathrm{kPa}$, injection pressure $160 \mathrm{kPa}$; Perkin Elmer Inc., Waltham, CT). A ${ }^{63} \mathrm{Ni}$ electron-capture detector was used to determine $\mathrm{N}_{2} \mathrm{O}$ concentrations and a flame ionization 
detector (FID) connected to a methanizer used to measure $\mathrm{CH}_{4}$ and $\mathrm{CO}_{2}$. The temperatures of the injector, oven and detector were $40{ }^{\circ} \mathrm{C}, 40{ }^{\circ} \mathrm{C}$ and $375{ }^{\circ} \mathrm{C}$, respectively. Fluxes were estimated as the slope of the linear regression between concentrations and time $(1 \mathrm{~h})$ after corrections for temperature, and from the ratio between chamber volume and soil surface area (MacKenzie et al., 1998). Cumulative fluxes were estimated using the trapezoidal rule (SanzCobena et al., 2014), multiplying the mean of two successive daily fluxes by the number of hours between the two measurements and adding that amount to the previous cumulative total. The global warming potential (GWP) of $\mathrm{CH}_{4}, \mathrm{CO}_{2}$ and $\mathrm{N}_{2} \mathrm{O}$ were estimated in $\mathrm{CO}_{2}$ equivalents by multiplying the cumulative fluxes at the end of the experiment by 34 for $\mathrm{CH}_{4}, 1$ for $\mathrm{CO}_{2}$ and by 298 for $\mathrm{N}_{2} \mathrm{O}$ (IPCC, 2013).

\subsection{Soil microbial community analysis}

Phospholipid fatty acid (PLFA) analyses were carried out after collecting $25 \mathrm{~g}$ of soil from each container at the end of the flood stage, and at the end of the soil recovery stage. After collection, the samples were frozen at $-80^{\circ} \mathrm{C}$ until analysis. PLFA analysis was undertaken as detailed in Bartelt-Ryser et al. (2005). Although a total of 107 fatty acids were identified in the soil samples, Table A.1 shows the 35 that were subsequently used in the analysis because they had a concentration higher than $0.5 \%$ of the total PLFAs. These included biomarkers for Gram + and Gram - bacteria, actinomycetes, anaerobic bacteria (anaerobe), putative arbuscular mycorrhizal fungi (AM fungi), protozoa and fungi. Total PLFAs was used as a proxy of soil microbial biomass (SMB). Standard nomenclature followed that of Frostegård et al. (1993). From the individual PLFAs, different microbial abundance ratios were calculated including: Fungi-to-bacteria; predator-to-prey (protozoa/bacteria) to estimate the availability of nutrients; Gram +/Gram - as an indicator of soil aeration state (Bossio and Scow, 1998); saturated/unsaturated fatty acids (sat/unsat) to assess the stability of the microbial community. 
Ratios of mono/polyunsaturated fatty acids (mono/poly); precursor/cyclopropane fatty acids (precursor/cyclopropane fatty acids; and $16 \omega / 17$ cyclo and $18 \omega / 19$ cyclo) were used to identify possible stress (Knivett and Cullen, 1965).

\subsection{Statistical analysis}

Repeated measures analysis of variance (ANOVA) based on a completely randomized design for the 4 treatments (combination of two factors, flooding and manure application: control and manure with and without flooding), and 3 replicates per treatment were applied to soil solution $\mathrm{NH}_{4}{ }^{+}$and $\mathrm{NO}_{3}{ }^{-}$and daily fluxes of GHG for each combination of floodwater type $\times$ temperature. The same statistical analysis was applied to $\mathrm{NH}_{4}{ }^{+}$and $\mathrm{NO}_{3}{ }^{-}$in floodwater with only two treatments (control and manure with flooding). When the differences were significant, a Bonferroni multiple comparison test at a probability level of 0.05 was used to identify differences between treatments with time.

Factorial ANOVA based on a completely randomized design with two factors (manure and temperature) was carried out for $\mathrm{pH}$ and $\mathrm{EC}$ in floodwater, potential loss of nutrients, and with three factors (flooding, manure and temperature) for cumulative GHG fluxes and total GWP at the end of the experiment, and PLFAs (total PLFAs, taxonomic groups and PLFA ratios), independently, for freshwater and saline water containers. In these cases, Tukey's HSD post hoc was used to identify treatment differences.

Principal component analysis (PCA) was used to explore relationships between fatty acid profiles (PLFAs), GHG daily fluxes, $\mathrm{NH}_{4}{ }^{+}$and $\mathrm{NO}_{3}{ }^{-}$in soil solution, based on a data correlation matrix. Finally, Pearson correlations were carried out between these factors. All statistical analyses were performed using SPSS v22.0 (IBM Corp., Armonk, NY).

\section{Results}




\subsection{Initial soil, water and manure properties}

Soil and water properties are summarized in Table A.2. The soil was a sandy clay loam soil, with neutral $\mathrm{pH}$, a high organic matter content $\left(78 \pm 5 \mathrm{~g} \mathrm{~kg}^{-1}\right)$ and available $\mathrm{P}$ content (38 $\left.\pm 4 \mathrm{mg} \mathrm{kg}^{-1}\right)$, and a medium available $\mathrm{K}$ content $\left(122 \pm 11 \mathrm{mg} \mathrm{kg}^{-1}\right.$, Defra, 2010). The $\mathrm{pH}$ of the freshwater floodwater was lower than that of the saline floodwater, but the electrical conductivity of the saline floodwater was significantly greater, as expected. Although similar $\mathrm{NO}_{3}{ }^{-}$concentrations were found in both water types, $\mathrm{NH}_{4}{ }^{+}$and $\mathrm{P}$ were considerably higher in the saline water (Table A.2). Manure properties are shown in Table A.3, where typical values for broiler litter can be seen (e.g. low C:N ratio; Edwards and Daniel, 1992).

\subsection{Floodwater $\mathrm{pH}$ and electrical conductivity}

Throughout the 11 week flood period the $\mathrm{pH}$ of the floodwaters remained relatively constant with few treatment effects apparent (Table 1). Interactions between temperature and manure factors were found at the beginning and at the end of the flooding period for the fresh floodwater. The only major effect was the presence of manure which tended to increase floodwater $\mathrm{pH}$ relative to the control at both temperatures for saline water (no significant differences were found for freshwater). However, there was an interaction on day 77 due to the different effect that the temperature caused in the $\mathrm{pH}$ in presence and lack of manure $(p=$ $0.032)$.

The EC of the floodwater in the freshwater treatments increased over time, particularly in the manure treatments (Table 1). The interaction observed at the end of the flood phase for the fresh floodwater $(p<0.001)$ was due to the different effect that the temperature caused in the EC in the mesocosms with and without manure. As expected, the EC of the saline floodwater was greater than that of the freshwater treatments (two orders of magnitude higher), and whilst significant differences were not seen at the beginning of the flood phase, an 
interaction occurred at the end of that phase $(\mathrm{p}<0.001)$ when the control at $6{ }^{\circ} \mathrm{C}$ had the highest EC values).

\subsection{Dynamics of $\mathrm{NH}_{4}{ }^{+}$and $\mathrm{NO}_{3}{ }^{-}$during simulated river flooding}

The temporal dynamics of $\mathrm{NH}_{4}{ }^{+}$and $\mathrm{NO}_{3}{ }^{-}$in soil solution as a function of temperature, flooding and manure application are shown in Fig. 1. The $\mathrm{NH}_{4}{ }^{+}$concentration was initially higher for treatments including broiler litter and remained so throughout the experiment. In comparison, temperature had relatively little effect on soil $\mathrm{NH}_{4}{ }^{+}$levels. $\mathrm{NH}_{4}{ }^{+}$concentrations in the overlying floodwater in the non-amended treatments remained $<0.1 \mathrm{mg} \mathrm{N}^{-1}$ for the entire flood period, but increased from 10 to $40 \mathrm{mg} \mathrm{N}^{-1}$ in the broiler litter treatments (data not shown). After floodwater removal, soil solution $\mathrm{NH}_{4}{ }^{+}$concentrations remained high, declining very slightly over time in the manure treatments.

Soil solution $\mathrm{NO}_{3}{ }^{-}$concentrations were greater in the control treatments than the manure treatments at both temperatures at the start of the experiment. Nitrate concentrations then progressively declined in all treatments over the first 3 weeks. In the $6{ }^{\circ} \mathrm{C}$ treatments, soil solution $\mathrm{NO}_{3}{ }^{-}$concentrations remained low, even after the floodwater had been removed. At $14{ }^{\circ} \mathrm{C}$, soil solution $\mathrm{NO}_{3}{ }^{-}$concentration in the non-flooded manure treatment increased, particularly towards the end of the flooding period, at which point concentrations increased markedly, and continued to do so during the recovery period. Soil solution $\mathrm{NO}_{3}{ }^{-}$concentrations in the control non-flooded treatment also increased in the later stages of the flooding period. It was only on the last two measurement occasions (in the recovery phase), when the soil solution $\mathrm{NO}_{3}{ }^{-}$concentration in the flooded treatments started to increase (Figs. 1c, d).

Floodwater $\mathrm{NO}_{3}{ }^{-}$concentrations were initially greater in the control treatment compared to the manure treatment (negligible concentrations) at both temperatures (data not 
shown). Subsequently, $\mathrm{NO}_{3}{ }^{-}$concentrations in all floodwaters decreased to very low levels during the flooding period, with the rate of decrease being quicker at the higher temperature. Overall, temperature did not have a significant effect on the potential for nutrient loss for the flooded treatments (Table 2). However, the addition of manure significantly increased the potential for $\mathrm{NH}_{4}{ }^{+}$losses but decreased it for $\mathrm{NO}_{3}{ }^{-}$in comparison with treatments without manure (Table 2).

\subsection{Dynamics of $\mathrm{NH}_{4}{ }^{+}$and $\mathrm{NO}_{3}{ }^{-}$during simulated coastal flooding}

The impact of simulated coastal flooding on soil solution $\mathrm{NH}_{4}{ }^{+}$and $\mathrm{NO}_{3}{ }^{-}$ concentrations is shown in Fig 2. In general, soil solution $\mathrm{NH}_{4}{ }^{+}$concentrations increased during the experiment, although there was a marked decrease for manure treatments at $14{ }^{\circ} \mathrm{C}$ around day 50 (Fig. 2b). Control and control + flood treatments also experienced a general increase in $\mathrm{NH}_{4}{ }^{+}$in soil solution towards the end of the flood period (Figs. 2a and b). The $\mathrm{NH}_{4}{ }^{+}$ concentrations in the overlying floodwater in the non-amended treatments remained negligible for the entire flood period but increased from 40 to $65 \mathrm{mg} \mathrm{l}^{-1}$ in the manure treatments (data not shown).

An initial decrease in soil solution $\mathrm{NO}_{3}{ }^{-}$was observed for all treatments, and was more rapid at $14{ }^{\circ} \mathrm{C}$ than at $6{ }^{\circ} \mathrm{C}$. The flooded manure treatment at $14{ }^{\circ} \mathrm{C}$ had the lowest soil $\mathrm{NO}_{3}{ }^{-}$ concentration throughout the experiment (Figs. 2c and d). Some peaks were observed in soil solution $\mathrm{NO}_{3}{ }^{-}$for the control treatment at $6{ }^{\circ} \mathrm{C}$, and there was a gradual increase in soil solution $\mathrm{NO}_{3}{ }^{-}$concentrations in the non-flooded control and manure treatments at $14^{\circ} \mathrm{C}$ towards the end of the flooding period, that continued into the recovery period. Similar to the freshwater flood treatments, $\mathrm{NO}_{3}{ }^{-}$concentrations in the overlying floodwater decreased during the flooding period (from 20 to $\approx 5 \mathrm{mg} 1^{-1}$ at $6{ }^{\circ} \mathrm{C}$, and from 24 to $18 \mathrm{mg} 1^{-1}$ at $14{ }^{\circ} \mathrm{C}$ ) but were higher than those of the control treatment at both temperatures (almost negligible, data not shown). 
The addition of manure increased the $\mathrm{NH}_{4}{ }^{+}$loss potential, meanwhile the highest temperature $\left(14^{\circ} \mathrm{C}\right)$ and the application of manure reduced the values for potential losses of $\mathrm{NO}_{3}{ }^{-}$(Table 2).

\subsection{Greenhouse gas emissions during simulated river flooding}

Daily fluxes of $\mathrm{CH}_{4}, \mathrm{CO}_{2}$ and $\mathrm{N}_{2} \mathrm{O}$ are shown in Fig. 3 No $\mathrm{CH}_{4}$ emissions were

detectable from any treatment at $6{ }^{\circ} \mathrm{C}$. However, there were clear peaks in $\mathrm{CH}_{4}$ emissions towards the end of the flooding period and into the recovery phase (days 65-90) in the manure amended treatments, especially the flooded manure treatment. Subsequently, these fluxes decreased rapidly after floodwater removal (Fig. 3b). Peaks of daily $\mathrm{CO}_{2}$ fluxes were detected in the flooded manure treatment as the $\mathrm{CH}_{4}$ emissions declined during the recovery period at $14{ }^{\circ} \mathrm{C}$ (Fig. 3d). Finally, there were peaks in daily $\mathrm{N}_{2} \mathrm{O}$ fluxes on the first (at $6{ }^{\circ} \mathrm{C}$ and $14{ }^{\circ} \mathrm{C}$ ) and last days (at $6^{\circ} \mathrm{C}$ ) of the experiment for the non-flooded manure treatment (Figs. 3e and f). At $14{ }^{\circ} \mathrm{C}$, additional $\mathrm{N}_{2} \mathrm{O}$ fluxes were measured from the non-flooded manure treatment, especially after the soil was allowed to dry out in the recovery phase, when emissions were also seen for the flooded manure and flooded control treatments (Fig. 3f). increased by flooding, although cumulative $\mathrm{CO}_{2}$ and $\mathrm{N}_{2} \mathrm{O}$ emissions were lower (Table 3), such that the net cumulative GHG emission, expressed as $\mathrm{CO}_{2}$ equivalent, was increased. Cumulative emissions of all GHGs (and therefore GWP) were increased at $14{ }^{\circ} \mathrm{C}$ compared to $6{ }^{\circ} \mathrm{C}$, and GHG emissions were greater from manure-amended treatments. The multiple interactions were due to the different effects that flooding had on control and manure treatments: increased cumulative $\mathrm{CH}_{4}$ fluxes when manure was applied but only at $14{ }^{\circ} \mathrm{C}$; and reduced cumulative $\mathrm{N}_{2} \mathrm{O}$ fluxes also when manure was applied at both temperatures (details in Fig. 3). 


\subsection{Greenhouse gas emissions during simulated coastal flooding}

The daily fluxes of $\mathrm{CH}_{4}, \mathrm{CO}_{2}$ and $\mathrm{N}_{2} \mathrm{O}$ are shown in Fig. 4 The pattern of daily $\mathrm{CH}_{4}$

fluxes was similar to those observed for the freshwater, with peaks in emissions towards the end of the flooding period from the manure treatments at the higher temperature $\left(14{ }^{\circ} \mathrm{C}\right)$. However, these fluxes were much smaller than measured from the freshwater flooding. $\mathrm{CH}_{4}$ emissions decreased rapidly from the flooded manure treatment, once the floodwater was removed but the highest peak was reached immediately after water removal. Daily $\mathrm{CO}_{2}$ fluxes remained low at $6{ }^{\circ} \mathrm{C}$ from all treatments throughout the flooding phase (Fig. 4c), with some evidence of greater fluxes from the non-flooded manure treatment, especially after the soils were allowed to dry out in the extended recovery phase at both temperatures (Figs. 4c and d). Daily $\mathrm{N}_{2} \mathrm{O}$ fluxes were also similar to those measured from the freshwater treatments, with fluxes immediately after establishment of treatments at both temperatures. At $14{ }^{\circ} \mathrm{C}$ there was a small peak in $\mathrm{N}_{2} \mathrm{O}$ emission after the soil in the non-flooded manure treatment had been allowed to dry out in the recovery phase (Figs. 4e and f).

Flooding with saline water significantly reduced the cumulative $\mathrm{CO}_{2}$ and $\mathrm{N}_{2} \mathrm{O}$ fluxes (through the flooding and extended recovery phases), as well as total GHG emissions, expressed as $\mathrm{CO}_{2}$ equivalents (Table 3). Temperature increased the three GHG cumulative fluxes and, consequently the GWP. Manure application also increased cumulative emissions of $\mathrm{CH}_{4}$ and $\mathrm{CO}_{2}$ emissions, but decreased the $\mathrm{N}_{2} \mathrm{O}$ cumulative fluxes resulting in a nonsignificant effect on total GHG emissions, expressed as $\mathrm{CO}_{2}$ equivalents (Table 3). There were some interactions between temperature and manure for cumulative $\mathrm{CH}_{4}$ fluxes (manure increased this emissions only at $\left.14{ }^{\circ} \mathrm{C}, p=0.021\right)$ and $\operatorname{GWP}(p=0.017)$, and between flood and manure for cumulative $\mathrm{CO}_{2}(p=0.008)$ and $\mathrm{N}_{2} \mathrm{O}(p<0.001)$ fluxes (details in Fig. 4). 


\subsection{Soil microbial community changes during simulated river flooding}

Table 4 shows the SMB and the percentage of each taxonomic group estimated by the PLFAs after the flooding and recovery stages. In general, a lower SMB was observed after the soil recovery stage. Flood and temperature had a negative effect on SMB but there was a positive effect of manure application, probably due to the microbial population in the manure. Flooding facilitated the proliferation of Gram + bacteria (after soil recovery), including actinomycetes (after flood stage), but reduced the presence of Gram - bacteria and putative AM fungi (after soil recovery). The highest temperature resulted in a decrease in the percentage of fungi after the flooding stage, and Gram + bacteria and anaerobes after soil recovery stage, but increased the proportion of actinomycetes. Gram - bacteria were altered by temperature in the opposite sense in each analysis. Finally, the broiler litter treatment resulted in reduced Gram + bacteria after both stages and actinomycetes after both stages, anaerobes and putative AM fungi after soil recovery, but increased Gram - bacteria and fungi after both stages (Table 4). These alterations in microbial structure were also reflected in some PLFA ratios (Table A.4).

Fig. 5 shows the PCA for the different taxonomic groups (based on PLFAs), daily GHG

fluxes and nutrients in soil solution for the different combinations of flood $\times$ manure, the two temperatures $\left(6\right.$ and $\left.14{ }^{\circ} \mathrm{C}\right)$, and after the flood stage and the soil recovery stage. For $6{ }^{\circ} \mathrm{C}$ after the flooding stage (Fig. 5a), the differences between flooded and non-flooded (in this order) control treatments depended basically on putative AM fungi and actinomycetes, while flooded and non-flooded (in this order) manure treatments were more related to $\mathrm{NH}_{4}{ }^{+}, \mathrm{NO}_{3}{ }^{-}$contents in soil solution and fungi. After the soil recovery phase (Fig. 5b), the differences between treatments were less evident but changes in the same taxonomic groups were observed and daily $\mathrm{N}_{2} \mathrm{O}$ fluxes appeared to be more related to this in the non-flooded manure treatment. After the flood stage at $14{ }^{\circ} \mathrm{C}$ (Fig. 5c), changes in non-flooded control and flooded control treatments were more related to AM fungi, actinomycetes, Gram + bacteria and $\mathrm{NO}_{3}{ }^{-}$in soil 
solution. The non-flooded manure treatment depended on shifts in protozoa, fungi, Gram bacteria and high concentrations in $\mathrm{NH}_{4}{ }^{+}$in soil solution and the flooded manure with daily $\mathrm{CH}_{4}$ fluxes. Daily $\mathrm{N}_{2} \mathrm{O}$ and $\mathrm{CO}_{2}$ fluxes were important for one of the non-flooded manure samples. As occurred at $6{ }^{\circ} \mathrm{C}$, the differences due to the effect of the flooding were less clear after the soil recovery (Fig. 5d).

$\mathrm{NH}_{4}{ }^{+}$in soil solution was positively correlated with $16: 1 \mathrm{w} 7 \mathrm{c}(r=0.43, P=0.035)$ and negatively with 16:0 10 methyl $(r=-0.49, P=0.014)$ after the flood stage. Positive correlations between daily $\mathrm{CO}_{2} / \mathrm{N}_{2} \mathrm{O}$ fluxes and several fatty acids were found after soil recovery stage (total PLFAs, 15:0 anteiso, 16:1 w7c, 16:0, 17:0 cyclo w7c, 18:1 w9c, 18:1 w7c and 18:0 10 methyl). Additional correlations between daily GHG emissions and soil nutrients were also observed: $\mathrm{NH}_{4}{ }^{+}$was negatively correlated with $\mathrm{NO}_{3}{ }^{-}(r=-0.47, P=0.022$, after the flood stage, and $r=-0.40, P=0.052$, after the soil recovery) in soil solution, and positively with $\mathrm{CO}_{2}(r=0.61, P=0.002)$ and $\mathrm{N}_{2} \mathrm{O}(r=0.50, P=0.014)$ fluxes, after the flooding stage. Daily $\mathrm{CO}_{2}$ and $\mathrm{N}_{2} \mathrm{O}$ fluxes were highly positively correlated $(r=0.87, P<0.001)$ after the flood stage. After the soil recovery stage, $\mathrm{CH}_{4}-\mathrm{CO}_{2}(r=0.50, P=0.005)$ and $\mathrm{N}_{2} \mathrm{O}-\mathrm{CO}_{2}(r=0.64, P$ $<0.001)$ were also positively correlated.

\subsection{Soil microbial community changes during simulated coastal flooding}

The SMB was higher after the flooding stage than after the soil recovery stage (Table 5). In addition, the SMB was reduced by saline water flooding and at the highest temperature $\left(14{ }^{\circ} \mathrm{C}\right)$. Flooding increased the content of putative AM fungi (after both stages) but reduced protozoa after soil recovery. The highest temperature decreased the percentage of anaerobes (after soil recovery), putative AM fungi (after both stages) and protozoa (after soil recovery) and increased the content of Gram - bacteria (after soil recovery stage); Gram + bacteria were altered in the opposite sense in each case. Lastly, broiler litter addition reduced Gram + 
bacteria, actinomycetes, anaerobes and AM fungi after both stages, and protozoa after flooding stage, but increased the proportion of Gram - bacteria and fungi after both stages (Table 5). Changes in some PLFAs ratios are shown in Table A.4.

The PCA for the saline water mesocosms is shown in Fig. 6 After the flood stage at 6 ${ }^{\circ} \mathrm{C}$ (Fig. 6a), non-flooded control and flooded controls treatments (no clear differences between them) were related with $\mathrm{NO}_{3}{ }^{-}$in soil solution, putative AM fungi, protozoa and fungi . On the other hand, $\mathrm{NH}_{4}{ }^{+}$in soil solution, actinomycetes, daily $\mathrm{CO}_{2}$ flux and anaerobes were more related to both the flooded manure and the non-flooded manure treatments (in this order). After the soil recovery stage at $6{ }^{\circ} \mathrm{C}$ (Fig. 6b), non-flooded manure treatment and flooded manure treatments (in this order) were related to putative AM fungi, actinomycetes, anaerobes and Gram + bacteria, and non-flooded control and flooded control treatments (no differences between them) to $\mathrm{CO}_{2}$ and Gram - bacteria. Fungi and daily $\mathrm{CH}_{4}$ fluxes were important to differentiate between flooded and non-flooded manure treatments. Daily $\mathrm{N}_{2} \mathrm{O}$ fluxes were related with the flooded and non-flooded control treatments.

In the case of $14{ }^{\circ} \mathrm{C}$ after the flood stage (Fig. 6c), non-flooded control and flooded control treatments (no differences between them) were more related with Gram + bacteria, anaerobes, actinomycetes, daily $\mathrm{N}_{2} \mathrm{O}$ fluxes and $\mathrm{NO}_{3}{ }^{-}$in soil solution. The non-flooded manure treatment was best explained by changes in fungi, protozoa, daily $\mathrm{CO}_{2}$ fluxes and $\mathrm{NH}_{4}{ }^{+}$in soil solution and in the flooded manure treatment by Gram - bacteria, $\mathrm{NH}_{4}{ }^{+}$in soil solution and to a lesser extent with daily $\mathrm{CH}_{4}$ fluxes. After soil recovery (Fig. 6d) the results were quite similar to those obtained after the soil flood stage but the differences between non-flooded manure and flooded manure were less evident. Note the lack of effect of $\mathrm{CH}_{4}$ fluxes. acid $(r=-0.44, P=0.033)$ and a positive one between $\mathrm{NO}_{3}{ }^{-}$and 16:0 iso $(r=0.41, P=0.045)$ found after flood stage, positive correlations between $\mathrm{CO}_{2}$ fluxes and two fatty acids, 16:1w7c 
$(r=0.41, P=0.045)$ and $18: 1 \mathrm{w} 7 \mathrm{c}(r=0.43, P=0.037)$, and $\mathrm{N}_{2} \mathrm{O}$ and $16: 0$ fatty acid $(r=0.47$, $P=0.021)$ after soil recovery stage, were found. Furthermore, $\mathrm{NH}_{4}{ }^{+}-\mathrm{NO}_{3}{ }^{-}$were negatively correlated after the flood stage $(r=-0.40, P=0.052)$, and $\mathrm{CH}_{4}-\mathrm{CO}_{2}(r=0.52, P=0.010)$ and $\mathrm{CO}_{2}-\mathrm{N}_{2} \mathrm{O}(r=0.83, P<0.001)$ positively correlated after the soil recovery stage.

\section{Discussion}

\subsection{Impact of flood type on soil and water chemistry}

In most cases, the $\mathrm{pH}$ and $\mathrm{EC}$ of the floodwater and soil increased with time, although these effects were relatively small. As $\mathrm{pH}$ affects many soil processes and represents a major soil quality indicator, it suggests that $\mathrm{pH}$ may be an insensitive indicator of the damage caused by flooding. Our results, using a close-to-neutral soil ( $\mathrm{pH}$ 6.92, Table A.2), agree with Ponnamperuma (1972) who also showed that the $\mathrm{pH}$ of acidic soils increases under flooding due to the consumption of protons in reduction processes (i.e. $\mathrm{Fe}(\mathrm{OH})_{3} \rightarrow \mathrm{Fe}^{2+}, \mathrm{MnO}_{2} \rightarrow \mathrm{Mn}^{2+}$ ). This effect was more apparent in the manure treatments, presumably as its addition stimulated microbial activity, enhanced $\mathrm{O}_{2}$ depletion and induced greater reduction of metal oxyhydroxides.

Elevated soil solution $\mathrm{NH}_{4}{ }^{+}$concentrations in the manure-amended soils were attributable to the high uric acid and $\mathrm{NH}_{4}{ }^{+}$content in the broiler litter (Table A.3). This was more obvious when saline water was applied to the soil, possibly due to competition from high levels of added $\mathrm{Na}^{+}(459 \mathrm{mM})$, preventing $\mathrm{NH}_{4}^{+}$sorption to soil cation exchange sites. Although not shown by our data, the high soil salinity may have been cytotoxic, reducing the rate of microbial $\mathrm{N}$ immobilization (Azam and Ifzal, 2006). It is also well established that nitrification can be interrupted under anaerobic conditions (Nielsen et al., 1996), facilitating the accumulation of $\mathrm{NH}_{4}{ }^{+}$in soil and its diffusion into the overlying floodwater. It is notable that the concentrations of $\mathrm{NH}_{4}{ }^{+}$accumulated in our manure amended soils (ca. $3 \mathrm{mM}$ ) was 
within the range known to repress root growth in crops such as Arabidopsis thaliana (Liu et al., 2013), particularly when $\mathrm{NO}_{3}{ }^{-}$concentrations are very low (Zheng et al., 2015). This suggests that the flooded fields should be left for a few weeks before attempting crop establishment to allow any excess $\mathrm{NH}_{4}{ }^{+}$to be nitrified. After floodwater removal and soil drying, the accumulated $\mathrm{NH}_{4}{ }^{+}$may also result in excessive discharge of $\mathrm{NH}_{3}$ in high $\mathrm{pH}$ soils and this warrants further investigation. Further, after $\mathrm{O}_{2}$ is reintroduced into the soil a significant release of $\mathrm{N}_{2} \mathrm{O}$ may occur as a result of nitrification and denitrification processes, particularly in soils close to field capacity (Nielsen et al., 1996). Despite these potential negative effects, any $\mathrm{N}$ accumulated during an extreme flood event could be useful for plant growth and should be accounted for prior to applying fertilizers.

Evidence of nitrification (increases in $\mathrm{NO}_{3}{ }^{-}$and associated $\mathrm{N}_{2} \mathrm{O}$ emissions) was observed for the unflooded treatments (control and/or manure) at both temperatures and for both types of floodwater during the experiment. For the flooded treatments, nitrification was only detected at the end of the soil recovery stage in the case of freshwater, because this process is typically inhibited by the high water content (low oxygen status) of the soil. The absence of nitrification in saline flooded soils after water removal could be due to the negative effect of salts on the microbial community that facilitates the accumulation of $\mathrm{NH}_{4}{ }^{+}$in the soil solution in all cases (Blood et al., 1991). Nitrification is favoured at higher temperatures (with an optimum at $25-35{ }^{\circ} \mathrm{C}$; Focht and Verstraete, 1977); thereby, explaining the greater $\mathrm{NO}_{3}{ }^{-}$ concentrations observed at $14{ }^{\circ} \mathrm{C}$ during the 30-100 day period for unflooded treatments. Denitrification usually occurs in anoxic conditions and could explain the decrease in $\mathrm{NO}_{3}{ }^{-}$ concentrations in the floodwater of flooded control treatments during the flood stage. 

therefore, a potential source of GHG emissions (Chadwick et al., 2011). The fluxes of $\mathrm{CH}_{4}$ were only of significance for the non-flooded and flooded treatments at $14{ }^{\circ} \mathrm{C}$ in which broiler litter was applied, being higher for soils flooded with freshwater than those inundated with saline water (different orders of magnitude although no statistical analysis was done to compare them). These emissions are directly related to the decomposition of organic matter under anaerobic, highly reducing conditions (Bastone and Keller, 2003). The lack of $\mathrm{CH}_{4}$ emissions under the lower temperature regime probably reflects the reduced rates of microbial activity and the presence of other more microbially-favourable terminal electron acceptors remaining in the soil $\left(\mathrm{NO}_{3}{ }^{-}, \mathrm{Fe}^{3+}\right.$; Le Mer and Roger, 2007). The occurrence of $\mathrm{CH}_{4}$ emissions in the unflooded soils amended with manure indicated the presence of anaerobic zones, despite these treatments being maintained at field capacity. A similar effect was also observed when livestock slurry was injected into an aerated soil (Flessa and Beese, 2000). Alternatively, the $\mathrm{CH}_{4}$ release from soil after flood removal could be due to the slow release of $\mathrm{CH}_{4}$ previously trapped within the soil pore network as drying progresses (van der Gon et al., 1996).

The production of $\mathrm{CH}_{4}$ requires a strong negative redox potential in soil (lower than $-100 \mathrm{mV}$ ), which is expected after several weeks of flooding, and in the presence of labile C (Hou et al., 2000). This is consistent with the highest $\mathrm{CH}_{4}$ daily fluxes being detected at the end of the flood phase when alternative electronic acceptors have probably been exhausted (e.g. $\mathrm{NO}_{3}{ }^{-}, \mathrm{Fe}^{3+}, \mathrm{SO}_{4}{ }^{2-}$ ). The different order of magnitude in $\mathrm{CH}_{4}$ release observed for the two types of flooding could be explained by the negative effect of the salinity on the functioning of the microbial community (Blood et al., 1991), however, it is more likely that it is due to the high concentration of $\mathrm{SO}_{4}{ }^{2-}$ in seawater $(28 \mathrm{mM})$ favouring sulphate reduction $\left(\mathrm{SO}_{4}{ }^{2-} \rightarrow \mathrm{H}_{2} \mathrm{~S}\right)$ over methanogenesis $\left(\mathrm{CO}_{2} \rightarrow \mathrm{CH}_{4}\right) . \mathrm{CH}_{4}$ emissions were not detected when the soil moisture 
became drier (near 100 days of the experiment), indicating than aerobic conditions prevailed in those soils.

Total $\mathrm{CO}_{2}$ emissions were negatively affected by flooding and responded positively to temperature and manure application, factors that are known to directly influence the microbial turnover of soil organic matter. Indeed there was a clear increase in daily $\mathrm{CO}_{2}$ fluxes after the flooding stage at $14{ }^{\circ} \mathrm{C}$ (quicker in freshwater than saline water), as $\mathrm{CH}_{4}$ fluxes decreased, indicating the recovery of aerobic microbial activity as the soil oxygen status increased again. In addition, methanotrophy may have marginally contributed to the increased release of $\mathrm{CO}_{2}$ after water removal (Zhang et al., 2012).

In our experiment, denitrification processes were most likely responsible for the very low $\mathrm{NO}_{3}{ }^{-}$concentrations in solution and the increased $\mathrm{N}_{2} \mathrm{O}$ emissions at the beginning of the experiment (lower $\mathrm{NO}_{3}{ }^{-}$concentrations than the respective non-flooded treatments; Hou et al., 2000). The existence of peaks of $\mathrm{N}_{2} \mathrm{O}$ emissions observed at the beginning of the flood phase are in line with Hansen et al. (2014), who stated that these emissions are underestimated in agricultural soils under anaerobic conditions. Once oxygen was reintroduced to the soil, nitrification recommenced, promoting $\mathrm{NO}_{3}{ }^{-}$accumulation and $\mathrm{N}_{2} \mathrm{O}$ emissions in previously flooded treatments.

\subsection{Soil microbial community changes during simulated coastal flooding}

In line with previous studies, the PLFA biomarker approach proved useful to indicate the effects of prolonged flooding on soil microbial community structure (Bossio and Scow, 1998; Ferré et al., 2012). The quantity of soil microorganisms and the structure (also ratios) of the microbial community (PLFAs) varied as a function of fresh or saline water application. Fierer et al. (2003) stated that microorganisms are strongly affected by soil water content, temperature and organic matter among other parameters. Our results suggest that important 
changes in soil microbial community occurred due to extreme flooding ( $80 \mathrm{~d}$ of inundation) and that these changes persisted after flooding (observed more than $60 \mathrm{~d}$ of soil recovery). Unger et al. (2009) suggested that these changes are proportional to the time that floodwater remains on the soil. The decrease in microbial biomass at the end of the experiment could be explained according to de Groot and Van Wijck (1993) because the soil became drier. In addition, and as expected, flooding had negative consequences for PLFAs in both cases (after flood and recovery phases) (Unger et al., 2009). actinomycetes (branched fatty acids), and the decrease in Gram - bacteria (monounsaturated fatty acids) under flooding with freshwater agree with Bossio and Scow (1998) and Bai et al. (2000), respectively. This also affected the ratio of Gram +/Gram - (Table A.4). Gram + bacteria are assumed to be more resistant to stress (Guckert et al., 1985), but in our experiment their concentration was not altered by flood in the saline water treatments. Flooding increased the amount of putative AM fungi in the case of saline water. This was surprising, given the fact that no plants were growing in the soil and lends further credibility to the assumption that the PLFA markers for putative AM fungi (albeit very widely used) are not very specific (Sharma and Buyer, 2015). Further, work is clearly required to critically test these PLFA markers against specific molecular markers for AM fungi. Our results also indicated that soil fungal biomass was not significantly reduced in spite of previous studies showing them to be negatively affected by flooding (Bossio and Scow, 1995).

The variable effect that the temperature had on the percentage of the different taxonomic groups after the flood stage contrasts with the general decrease observed in the majority of groups associated with the dry soil at $14{ }^{\circ} \mathrm{C}$ at the end of the soil recovery stage.

577 These decreases were compensated by an increase in the percentages of Gram - bacteria, which 578 were more abundant in aerobic conditions for freshwater treatments (Guckert et al., 1985), and 
579 in actinomycetes for saline water treatments. The percentages of Gram - bacteria and fungi 580 were increased by poultry manure addition, in contrast with the decrease observed in the 581 majority of the taxonomic groups for the two kind of flooding. This is because aerobic 582 heterotrophs are known to use organic substrates more efficiently than anaerobic 583 microorganisms (Baldwin and Mitchell, 2000). The percentages of anaerobic bacteria 584 (anaerobes) were reduced when the oxic conditions replaced anoxic ones, as previously reported by Lynch and Hobbie (1988). The high manure nutrient content and its own intrinsic microbial community are plausible reasons of the increase in total microbial biomass after its application in freshwater treatments. Toyota and Kuninaga (2006) found that repeated applications of manure generated a new soil microbial community, however, in this experiment the microbial community significantly changed after only one application of broiler litter. decrease at low $\mathrm{O}_{2}$ availability and higher temperature (Knivett and Cullen, 1965). In our results, it was observed only for temperature, especially after the soil recovery stage (Table A.4). Our results, in which the precursor/cyclopropane ratios were higher after flood stage for flooded soils treated with saline water, are different to those detailed in Knivett and Cullen (1965).

The soils treated with manure were more associated with lower PLFA concentrations,

597 Gram - bacteria (especially in freshwater), higher GHG emissions, higher $\mathrm{NH}_{4}{ }^{+}$and lower $598 \mathrm{NO}_{3}{ }^{-}$concentrations after flooding than their non-flooded counterparts. The positive 599 correlations between total PLFAs and some fatty acids, and daily $\mathrm{CO}_{2} / \mathrm{N}_{2} \mathrm{O}$ emissions after the 600 soil recovery phase in freshwater treatments are evidence of microbial processes, such as nitrification. The differences between treatments were less evident after the soil recovery phase, indicating that the soil microbial community may have recovered to some extent. 

methanotrophs: type I (16:1 w7c). These are also found in ammonia-oxidizing bacteria (Bedard

605 and Knowles, 1989) that participate in the nitrification process (Kowalchuk and Stephen, 2001). In our experiment they were positively correlated with the soil solution $\mathrm{NH}_{4}{ }^{+}$(high in soil solution of flooded and non-flooded manure treatments) under freshwater but not under saline water after the flood stage; and type II, 18:1 w9c (Bowman et al., 1991, 1993). These two fatty acids are precursors of cyclopropane fatty acids under stress conditions. The lack of a positive correlation between 16:1 w7c fatty acid and soil solution $\mathrm{NH}_{4}{ }^{+}$concentration, besides the lack of $\mathrm{N}_{2} \mathrm{O}$ emissions of the flooded manure treatment under saline water during the soil recovery, could be an indication of the negative effect of this kind of flooding on nitrification after the water recedes although further work is needed to confirm this.

\section{Conclusions}

This study enhances our understanding of how extreme flood events alter soil functioning and consequently the delivery of ecosystem services within agroecosystems. We clearly show that different temperatures (winter/spring inundations), agricultural practices (manure application) and sources of floodwater alter C and N cycling, GHG emissions and microbial communities in different ways. This indicates that the precise response of soils to flooding is likely to be highly dependent on the local edaphic and management conditions as well as the typology of the flood event itself. It also suggests that the development of universal strategies to minimize and alleviate the negative impact of flooding may prove difficult. On balance, our results suggest that warmer flooding conditions result in greater negative impacts on soil and water quality. Although simulated coastal flooding resulted in lower GHG emissions than riverine flooding, the high salinity of marine waters may severely impact on other key aspects of soil functioning, such as soil structural stability, mesofaunal activity and 
plant growth. Further work is therefore needed to explore the longer-term effects of the different flood typologies, particularly at the field scale, where their impact on a wider range of soil properties and ecosystem services can be investigated.

\section{References}

Azam, F., Ifzal, M., 2006. Microbial populations immobilizing $\mathrm{NH}_{4}{ }^{+}-\mathrm{N}$ and $\mathrm{NO}_{3}{ }^{-}-\mathrm{N}$ differ in their sensitivity to sodium chloride salinity in soil. Soil Biol. Biochem. 38, 2491-2494.

Bai, Q., Gattinger, A., Zelles, L., 2000. Characterisation of microbial consortia in paddy rice soil by phospholipid analysis. Microb. Ecol. 39, 273-281.

Baldwin, D.S., Mitchell, A.M., 2000. The effects of drying and re-flooding on the sediment and soil nutrient dynamics of lowland river-floodplain systems: a synthesis. Regul. River. $16,457-467$.

Bartelt-Ryser, J., Joshi, J., Schmid, B., Brandl, H., Balser, T., 2005. Soil feedbacks of plant diversity on soil microbial communities and subsequent plant growth. Perspect. Plant Ecol. Evolut. Syst. 7, 27-49.

Bastone, D.J., Keller, J., 2003. Industrial applications of the IWA anaerobic digestion model no.1 (ADM1). Water Sci. Technol. 47, 199-206.

Bedard, C., Knowles, R., 1989. Physiology, biochemistry, and specific inhibitors of $\mathrm{CH}_{4}, \mathrm{NH}_{4}^{+}$, and CO oxidation by methanotrophs and nitrifiers. Microbiol. Rev. 53, 68-84.

Blood, E.R., Anderson, P., Smith, P.A., Nybro, C., Ginsberg, K.A., 1991. Effects of hurricane Hugo on coastal soil solution chemistry in South Carolina. Biotropica 23, 348-355.

Bossio, D.A., Scow, K.M., 1995. Impact of carbon and flooding on the metabolic diversity of microbial communities in soils. Appl. Environ. Microbiol. 61, 4043-4050. 
Bossio, D.A., Scow, K.M., 1998. Impacts of carbon and flooding on soil microbial communities: phospholipid fatty acid profiles and substrate utilization patterns. Microb. Ecol. 35, 265-278.

Bowman, J.P., Skerratt, J.H., Nichols, P.D., Sly, L.I., 1991. Phospholipid fatty-acid and lipopolysaccharide fatty-acid signature lipids in methane-utilizing bacteria. FEMS Microbiol. Ecol. 85, 15-22.

Bowman, J.P., Sly, L.I., Nichols, P.D., Hayward, A.C., 1993. Revised taxonomy of the methanotrophs - description of Methylobacter gen-nov, emendation of Methylococcus, validation of Methylosinus and Methylocystis species, and a proposal that the family Methylococcaceae includes only the group-I methanotrophs. Int. J. Syst. Evol. Bacteriol. $43,735-753$.

Chadwick, D., Sommer, S., Thornman, R., Fangueiro, D., Cardenas, L., Amon, B., Misselbrook, T., 2011. Manure management: Implications for greenhouse emissions. Anim. Feed Sci. Technol. 166-167, 514-531.

Cox, G.B., Loscombe, C.R., Upfield, J.A, 1996. The determination of uric acid in animal feeding stuffs using high-performance liquid chromatography. Analyst 101, 381-385.

de Groot, C., Van Wijck, C., 1993. The impact of desiccation of a freshwater marsh (Garcines Nord, Camargue, France) on sediment-water-vegetation interactions. Part one: the sediment chemistry. Hydrobiologia 252, 83-94.

Defra, 2010. Environmental Permitting Guidance. The IPPC Part A(1) Installations and Part A(1) Mobile Plant. Department for Environment, Food \& Rural Affairs, London, UK.

Defra, 2014. Legacy effects of extreme flood events on soil quality and ecosystem functioning: Project LM0316 Final Report. Department for Environment, Food \& Rural Affairs, London, UK. 
675 Edwards, D.R., Daniel, T.C., 1992. Environmental impacts of on-farm poultry waste-disposal

676

677

678

679

680

681

682

683

684

685

686

687

688

689

690

691

692

693

694

695

696

697

698

699 - a review. Bioresour. Technol. 41, 9-33.

EPA, 1996. Method 3050B. Acid Digestion of Sediments, Sludges, and Soils. Revision 2, in: U.S. E.P.A. (Ed.), Test Methods for Evaluating Solid Wastes: Physical/Chemical Methods, EPA SW-846, Third Ed., Vol. I, Section A, Chapter 3 (Inorganic Analytes), U.S. Environmental Protection Agency, Office of Solid Waste and Emergency Response, Washington, D.C. pp. 3050B-1-3050B-12, U.

Ferré, C., Zechmeister-Boltenstern, S., Comolli, R., Andersson, M., Seufert, G., 2012. Soil microbial community structure in a rice paddy field and its relationships to $\mathrm{CH}_{4}$ and $\mathrm{N}_{2} \mathrm{O}$ fluxes. Nutr. Cycl. Agroecosys. 93, 35-50.

Fierer, N., Schimel, J.P., Holden, P.A., 2003. Variations in microbial community composition through two soil depth profiles. Soil Biol. Biochem. 35, 167-176.

Flessa, H., Beese, F., 2000. Laboratory estimates of trace gas emissions following surface application or injection of cattle slurry. J. Environ. Qual. 29, 262-268.

Focht, D.D., Verstraete, W., 1977. Biochemical ecology of nitrification and denitrification, in: Alexander, M. (Ed.), Advances in Microbial Ecology. Plenum Press, New York, 1, pp. $135-214$.

Frostegård, Å., Bååth, E., Tunlid, A., 1993. Shifts in the structure of soil microbial communities in limed forests as revealed by phospholipid fatty acid analysis. Soil Biol. Biochem. 25, $723-730$.

Gee, G.W., Bauder, J.W., 1986. Particle-size analysis, in: Klute, A. (Ed.), Methods of Soil Analysis. Part 1. Physical and Mineralogical Methods, 9. American Society of Agronomy Monograph, Madison, WI, pp. 383-411.

Granli, T., Bøckman, O.C., 1994. Nitrous oxide from agriculture. Norw. J. Agric. Sci. 12, 128128. 
Guckert, J.B., Antworth, C.P., Nichols, P.D., White, D.C., 1985. Phospholipid, ester-linked fatty acid profiles as reproducible assays for changes in prokaryotic community structure of estuarine sediments. FEMS Microbiol. Lett. 31, 147-158.

Haigh, I.D., Wadey, M.P., Wahl, T., Ozsoy, O., Nicholls, R.J., Brown, J.M., Horsburgh, K., Gouldby, B., 2016. Storm surge events around the coastline of the UK. Scientific Data 3, UNSP 160107.

Hansen, M., Clough, T.J., Elberling, B., 2014. Flooding-induced emission bursts controlled by pH and nitrate in agricultural soils. Soil Biol. Biochem. 69, 17-24.

Herzog, M., Striker, G.G., Colmer, T.D., Pedersen, O., 2016. Mechanisms of waterlogging tolerance in wheat - a review of root and shoot physiology. Plant Cell Environ. 39, 10681086.

Hou, A.X., hen, G.X., Wang, Z.P., Van Cleemput, O., Patrick Jr., W.H., 2000. Methane and nitrous oxide emissions form a rice field in relation to soil redox and microbiological processes. Soil Sci. Soc. Am. J. 64, 2180-2186.

Huber, B., Luster, J., Bernasconi, S.M., Shrestha, J., Graf Pannatier, E., 2012. Nitrate leaching from short-hydroperiod floodplain soils. Biogeosciences 9, 4385-4397.

IPCC, 2013. Climate Change 2013: The Physical Science Basis. Contribution of Working Group I to the Fifth Assessment Report of the Intergovernmental Panel on Climate Change, in: Stocker, T.F., Qin, D., Plattner, G.K., Tignor, M., Allen, S.K., Boschung, J., Nauels, A., Xia, Y., Bex, V., Midgley, P.M. (Eds.). Cambridge University Press, Cambridge, United Kingdom and New York, NY, USA, 1535 pp.

Jones, D. L., V. B. Willett, 2006. Experimental evaluation of methods to quantify dissolved organic nitrogen (DON) and dissolved organic carbon (DOC) in soil. Soil Biol. Biochem. 38, 991-999, 
Kieft, T.L., Ringelberg, D.B., White, D.C., 1994. Changes in ester linked phospholipid fatty acid profiles of subsurface bacteria during starvation and desiccation in a porous medium. Appl. Environ. Microbiol. 60, 3292-3299.

Knivett, V.A., Cullen, J., 1965. Some factors affecting cyclopropane acid formation in Escherichia coli. Biochem. J. 96, 771-776.

Kowalchuk, G.A., Sthepen, J.R., 2001. Ammonia-oxidizing bacteria: a model for molecular microbial ecology. Annu. Rev. Microbiol. 55, 485-529.

Le Mer J., Roger P., 2001. Production, oxidation, emission and consumption of methane by soils: A review. Eur. J. Soil Biol. 37, 25-50.

Liu, Y., Lai, N.W., Gao, K., Chen, F.J., Yuan, L.X., Mi, G.H., 2013. Ammonium inhibits primary root growth by reducing the length of meristem and elongation zone and decreasing elemental expansion rate in the root apex in Arabidopsis thaliana. Plos One 8, e61031.

Liu, X.-J. A., Sun, J., Mau, R.L., Finley, B.K., Compson, Z.G., van Gestel, N., Brown, J.R., Schwartz, E., Dijkstra, P., Hungate, B.A., 2017. Labile carbon input determines the direction and magnitude of the priming effect Appl Soil Ecol. 109, 7-13.Lynch, J.M., Hobbie, J.E, 1988. Micro-organisms in Action: Concepts and Applications in Microbial Ecology, $2^{\text {nd }}$ edition. Blackwell, Melbourne.

Mackenzie, A.F., Fan, M.S., Cadrin, F., 1998. Nitrous oxide emission in three years as affected by tillage, corn-soybean-alfalfa rotations, and nitrogen fertilization. J. Environ. Qual. 27, 698-703.

Madan, R., Pankhurst, C., Hawke, B., Smith, S., 2002. Use of fatty acids for identification of AM fungi and estimation of the biomass of AM spores in soil. Soil Biol. Biochem. 34, $125-128$. 
Masunga, R.H., Uzokwe, V.N., Mlay, P.D., Odeh, I., Singh, A., Buchan, D., de Neve, S., 2016. Nitrogen mineralization dynamics of different valuable organic amendments commonly used in agriculture. Appl. Soil Ecol. 101, 185-193.

Met Office - United Kingdom, 2014. The Recent Storms and Floods in the UK. Available at: http://www.metoffice.gov.uk/media/pdf/1/2/Recent_Storms_Briefing_Final_SLR_2014 0211.pdf

Miranda, K.M, Espey, M.G., Wink, D.A., 2001. A rapid simple spectrophotometric method for simultaneous detection of nitrate and nitrite. Nitric Oxide. Biol. Chem. 5, 62-71.

Mulvaney, R.L., 1996. Nitrogen - inorganic forms, in: Sparks, D.L. (Ed.), Methods of Soil Analysis. Part 3. Chemical Methods. SSSA, Madison, WI, pp. 1123-1184.

Murphy, J., Riley, J.P., 1962. A modified single solution method for the determination of phosphate in natural waters. Anal. Chim. Acta 27, 31-36.

Nguyen, S.G., Guevarra, R.B., Kim, J., Ho, C.T., Trinh, M.V., Unno, T., 2015. Impacts of initial fertilizers and irrigation systems on paddy methanogens and methane emission. Water Air Soil Pollut. 226, 309.

Nicholls, R.J., Hoozemans, F.M.J., Marchand, M., 1999. Increasing flood risk and wetland losses due to global sea-level rise: regional and global analyses. Global Environ. Chang. 9, 69-87.

Nielsen, T.H., Nielsen, L.P., Revsbech, N.P., 1996. Nitrification and coupled nitrificationdenitrification associated with a soil-manure interface. Soil Sci. Soc. Am. J. 60, 18291840.

Niklaus, P.A., Alphei, J., Ebersberger, D., Kampichler, D., Kandeler, E., Tscherko, D., 2003. Six years of in situ $\mathrm{CO}_{2}$ enrichment evoke changes in soil structure and soil biota of nutrient-poor grassland. Global Change Biol. 9, 585-600. 
Niu, S., Luo, Y., Li, D., Cao, S., Xia, J., Li, J., Smith, M.D., 2014. Plant growth and mortality under climatic extremes: An overview. Environ. Exp. Bot. 98, 13-19.

Norton, J.M., 2008. Nitrification in agricultural soils, in: Schepers, J.S., Raun, W.R. (Eds.), Nitrogen in Agricultural Systems. Agron. Monogr. 49. American Society of Agronomy, Crop Science Society of America, Soil Science Society of America, Madison, Wisconsin, (Ch. 6), pp. 173-199.

Olsson, P.A., Thingstrup, I., Jakobsen, I., Baath, F., 1999. Estimation of the biomass of arbuscular mycorrhizal fungi in a linseed field. Soil. Biol. Biochem. 31, 1879-1887.

Pall, P., Aina, T., Stone, D.A., Stott, P.A., Nozawa, T., Hilberts, A.G.J., Lohmann, D., Allen, M.R., 2011. Anthropogenic greenhouse gas contribution to flood risk in England and Wales in autumn 2000. Nature 470, 382-385.

Paul, E.A., Clark, F.E., 1996. Soil Microbiology and Biochemistry. Academic Press, San Diego.

Peng, S.Z., Yang, S.H., Xu, J.Z., Gao, H.Z., 2011. Field experiments on greenhouse gas emissions and nitrogen and phosphorus losses from rice paddy with efficient irrigation and drainage management. Sci. China Technol. Sci. 54, 1581-1587.

Pereira, J., Figuereido, N., Goufo, P., Carneiro, J., Morais, R., Carranca, C., Coutinho, J., Trindade, H., 2013. Effects of elevated temperature and atmospheric carbon dioxide concentration on the emissions of methane and nitrous oxide from Portuguese flooded rice fields. Atmos. Environ. 80, 464-471.

Pohl, B., Macron, C., Monerie, P.A., 2017. Fewer rainy days and more extreme rainfall by the end of the century in Southern Africa. Sci. Rep. 7, 46466.

Ponnamperuma, F.N., 1972. The Chemistry of Submerged Soils. Academic Press, New York and London.

Ratledge, C., Wilkinson, S.G., 1988. Microbial Lipids. Academic Press, London. 
Robertson, G.P., Groffman, P.M., 2007. Nitrogen transformation, in: Paul, E.A. (Ed.), Soil Microbiology, Bio-chemistry, and Ecology. Springer, New York, NW, pp. 341-361.

Romanescu, G., Stoleriu, C.C., 2017. Exceptional floods in the Prut basin, Romania, in the context of heavy rains in the summer of 2010. Nat. Hazard. Earth Sys. Sci. 17, 381-396.

Sanz-Cobena, A., García-Marco, S., Quemada, M., Gabriel, J. L., Almendros, P., Vallejo, A., 2014. Do cover crops enhance $\mathrm{N}_{2} \mathrm{O}, \mathrm{CO}_{2}$ or $\mathrm{CH}_{4}$ emissions from soil in Mediterranean arable systems? Sci. Total. Environ. 466, 164-174.

Scalenghe, R., Edwards, A.C., Barberis, E., Ajmone-Marsan, F., 2012. Are agricultural soils under a continental temperate climate susceptible to episodic reducing conditions and increased leaching of phosphorus? J. Environ. Manage. 97, 141-147.

Sharma, M.P., Buyer, J.S., 2015. Comparison of biochemical and microscopic methods for quantification of arbuscular mycorrhizal fungi in soil and roots. Appl. Soil Ecol. 95, 8689.

Sibley, A., Cox, D., Titley, H., 2015. Coastal flooding in England and Wales from Atlantic and North Sea storms during the 2013/2014 winter. Weather 70, 62-70.

Smith, A., Porter, J.J., Upham, P., 2017. "We cannot let this happen again": reversing UK flood policy in response to the Somerset Levels floods, 2014. J. Environ. Plan. Manag. 60, $351-369$.

Snyder, C.S., Bruulsema, T.W., Jensen, T.L., Fixen, P.E., 2009. Review of greenhouse gas emissions from crop production systems and fertilizer management effects. Agr. Ecosyst. Environ. 133, 247-266.

Toyota, K., Kuninaga, S., 2006. Comparison of soil microbial community between soils amended with or without farmyard manure. Appl. Soil Ecol. 33, 39-48.

Unger, I.M., Kennedy, A.C., Muzika, R.M, 2009. Flooding effects on soil microbial communities. Appl. Soil Ecol. 42, 1-8. 
van der Gon, H.A.C., van Breemen, N., Neue, H.U., Lantin, R.S., Aduna, J.B., Alberto, M.C.R., Wassmann, R., 1996. Release of entrapped methane from wetland rice fields upon soil drying. Glob. Biogeochem. Cycle 10, 1-7.

Wang, Y., Yang, H., Ye, C., Chen, X., Xie, B., Huang, C., Zhang, J., Xu, M., 2013. Effects of plant species on soil microbial processes and $\mathrm{CH}_{4}$ emission from constructed wetlands. Environ. Pollut. 174, 273-278.

White, J.R., Reddy, K.R., 2009 Biogeochemical Dynamics I: Nitrogen Cycling in Wetlands, in Maltby, E., Barker, T., The Wetlands Handbook (Eds), The Wetlands Handbook. WileyBlackwell, Oxford, UK.

WMO, 2013. The Global Climate 2001-2010: A Decade of Climate Extremes. Geneva. Available at: http://www.wmo.int/pages/mediacentre/press_releases/pr_976_en.html

Zelles, L., 1999. Fatty acids patterns of phospholipids and lipopolysaccharides in the characterization of microbial communities in soil: a review. Biol. Fert. Soils 29, 111129.

Zhang, G.B., Ji, Y., Ma, J., Xu, H., Cai, Z.C., Yagi, K., 2012. Intermittent irrigation changes production, oxidation, and emission of $\mathrm{CH}_{4}$ in paddy fields determined with stable carbon isotope technique. Soil Biol. Biochem. 52, 108-116.

Zhang, Y., Sheng, J., Wang, Z., Chen, L., Zheng, J., 2015. Nitrous oxide and methane emissions from a Chinese wheat-rice cropping system under different tillage practices during the wheat-growing season. Soil Till. Res. 146, 261-269.

Zheng, X.J., He, K., Kleist, T., Chen, F., Luan, S., 2015. Anion channel SLAH3 functions in nitrate-dependent alleviation of ammonium toxicity in Arabidopsis. Plant Cell Environ. $38,474-486$.

Zhong-Cheng, L., Qi-Gen, D., Shi-Chao, Y., Fu-Guan, W., Yu-Shu, J., Jing-Dou, C., Lu-Shen, X., Hong-Cheng, Z., Zhong-Yang, H., Ke, X., Hai.Yan, W., 2012. Effects of nitrogen 
application levels on ammonia volatilization and nitrogen utilization during rice season. Rice. Sci. 19, 125-134.

\section{$850 \quad$ Figure captions}

851 Fig. 1. Temporal dynamics (mean of three replicates per combination of factors) of $\mathrm{NH}_{4}{ }^{+}$and $852 \mathrm{NO}_{3}{ }^{-}$in soil solution as a function of treatments and temperature under freshwater application. Vertical bars in the upper part of the figure represent Bonferroni values at $\alpha=0.05$. The dashed vertical line before 80 days indicates the separation between flood stage (left) and soil recovery stage (right). The second dashed vertical line indicates the end of the soil recovery keeping soil moisture at field capacity. C: control (without manure); $\mathrm{C}+\mathrm{F}$ : control + flood (without manure); M: manure application; M+F: manure application + flood.

Fig. 2. Temporal dynamics (mean of three replicates per combination of factors) of $\mathrm{NH}_{4}{ }^{+}$and $\mathrm{NO}_{3}{ }^{-}$in soil solution as a function of treatments and temperature under saline water application. Vertical bars in the upper part of the figure represent Bonferroni values at $\alpha=0.05$. The dashed vertical line before 80 days indicates the separation between flood stage (left) and soil recovery stage (right). The second dashed vertical line indicates the end of the soil recovery keeping soil moisture at field capacity. C: control (without manure); $\mathrm{C}+\mathrm{F}$ : control + flood (without manure); M: manure application; M+F: manure application + flood.

Fig. 3. Daily greenhouse gas fluxes (mean of three replicates per combination of factors) as a function of combination of factors for freshwater treatments. Vertical bars in the upper part of the figure represent Bonferroni values at $\alpha=0.05$. The dashed vertical line before 80 days indicates the separation between flood stage (left) and soil recovery stage (right) and the dashed vertical line before 100 days, between soil recovery stage in which soil samples were kept at 
field capacity (left) and the last stage in which no water was added. C: control (without manure); $\mathrm{C}+\mathrm{F}$ : control + flood (without manure); $\mathrm{M}$ : manure application; $\mathrm{M}+\mathrm{F}$ : manure application + flood

Fig. 4. Daily greenhouse gas fluxes (mean of three replicates per combination of factors) as a function of combination of factors for saline water treatments. Vertical bars in the upper part of the figure represent Bonferroni values at $\alpha=0.05$. The dashed vertical line before 80 days indicates the separation between flood stage (left) and soil recovery stage (right) and the dashed vertical line before 100 days, between soil recovery stage in which soil samples were kept at field capacity (left) and the last stage in which no water was added. C: control (without manure); $\mathrm{C}+\mathrm{F}$ : control + flood (without manure); $\mathrm{M}$ : manure application; $\mathrm{M}+\mathrm{F}$ : manure application + flood

Fig. 5. Principal component analysis for PLFAs (taxonomic groups), daily GHG emissions, and nutrients in soil solution $\left(\mathrm{NH}_{4}{ }^{+}, \mathrm{NO}_{3}{ }^{-}\right)$after flood stage and after soil recovery stage as a function of the combinations of factors for freshwater treatments after the flood stage and after the soil recovery stage. The separation between treatments is shown at the left and the corresponding loading of each variable included in the PCA at the right. C: control (without manure); $\mathrm{C}+\mathrm{F}$ : control + flood (without manure); $\mathrm{M}$ : manure application; $\mathrm{M}+\mathrm{F}$ : manure application + flood; circles and triangles are used for $6{ }^{\circ} \mathrm{C}$, and squares and inverted triangles for $14{ }^{\circ} \mathrm{C}$; empty symbols for unflooded soils and full symbols for flooded soils. The percentage of total variance explained by each principal component (PC) is shown in brackets.

Fig. 6. Principal component analysis for PLFAs (taxonomic groups), daily GHG emissions, and nutrients in soil solution $\left(\mathrm{NH}_{4}{ }^{+}, \mathrm{NO}_{3}{ }^{-}\right)$after flood stage and after soil recovery stage as a 
897 function of the combinations of factors for saline water treatments after the flood stage and 898 after the soil recovery stage. The separation between treatments is shown at the left and the 899 corresponding loading of each variable included in the PCA at the right. C: control (without 900 manure); $\mathrm{C}+\mathrm{F}$ : control + flood (without manure); $\mathrm{M}$ : manure application; $\mathrm{M}+\mathrm{F}$ : manure 901 application + flood; circles and triangles are used for $6{ }^{\circ} \mathrm{C}$, and squares and inverted triangles 902 for $14{ }^{\circ} \mathrm{C}$; empty symbols for unflooded soils and full symbols for flooded soils. The percentage 903 of total variance explained by each principal component (PC) is shown in brackets. 


\section{Freshwater - Soil solution}

$6{ }^{\circ} \mathrm{C}$

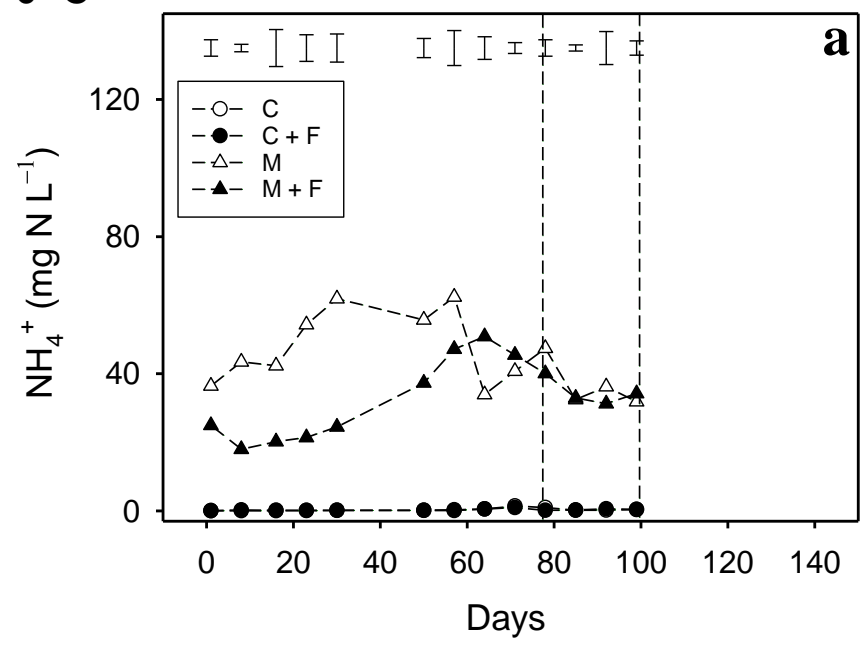

$6{ }^{\circ} \mathrm{C}$

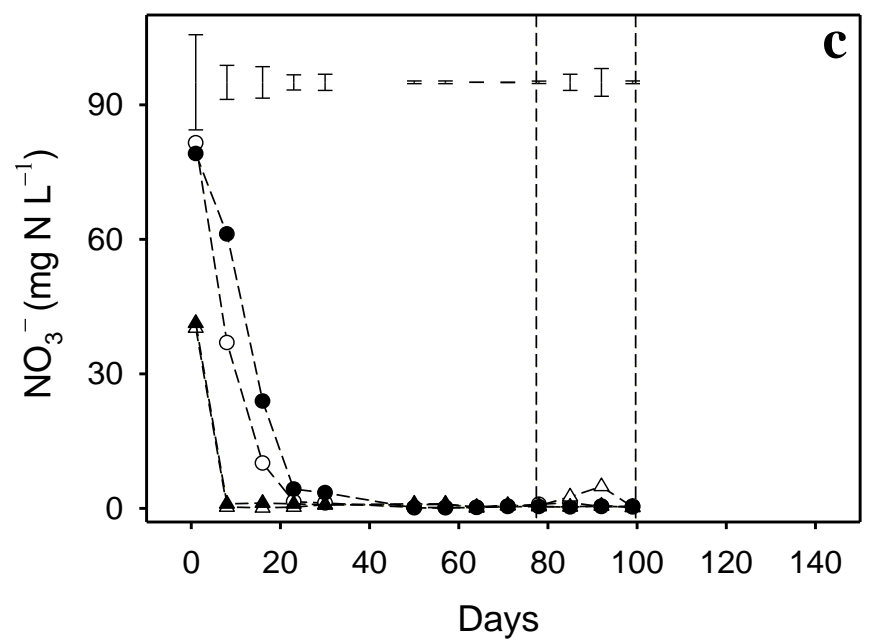

Figure 1 $14^{\circ} \mathrm{C}$

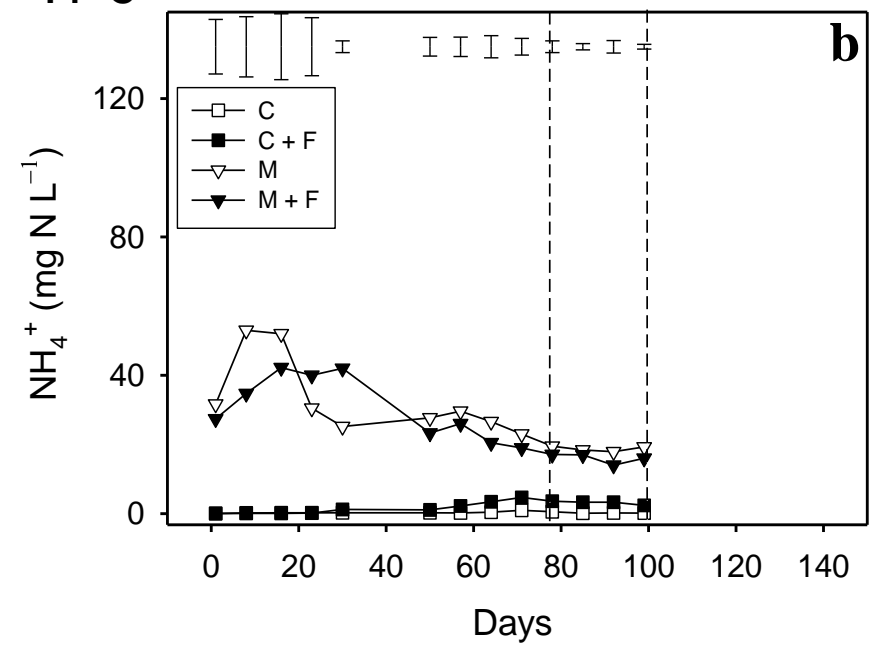

$14{ }^{\circ} \mathrm{C}$

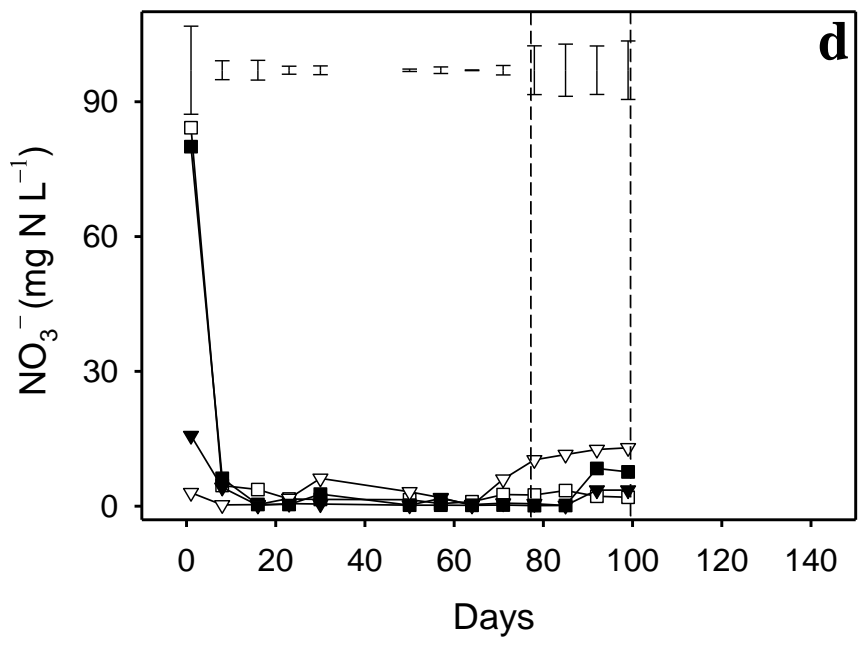




\section{Freshwater}

\section{After flood stage}

$6{ }^{\circ} \mathrm{C}$

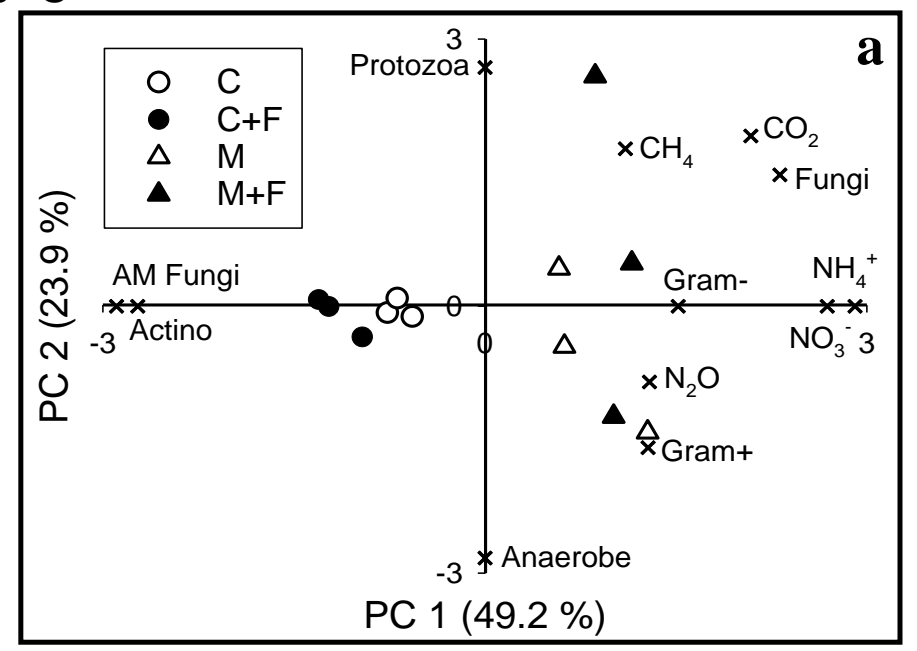

$14{ }^{\circ} \mathrm{C}$

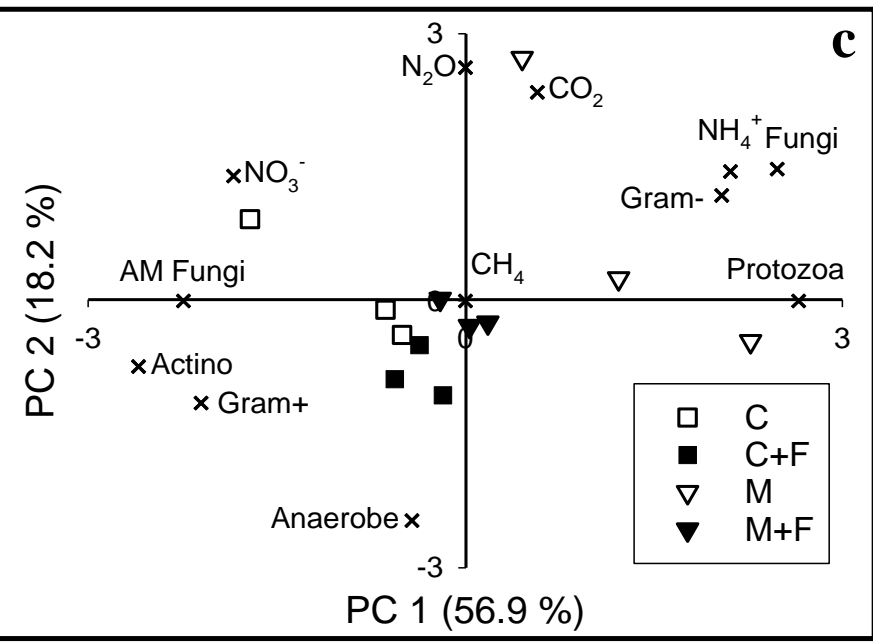

c $14^{\circ} \mathrm{C}$

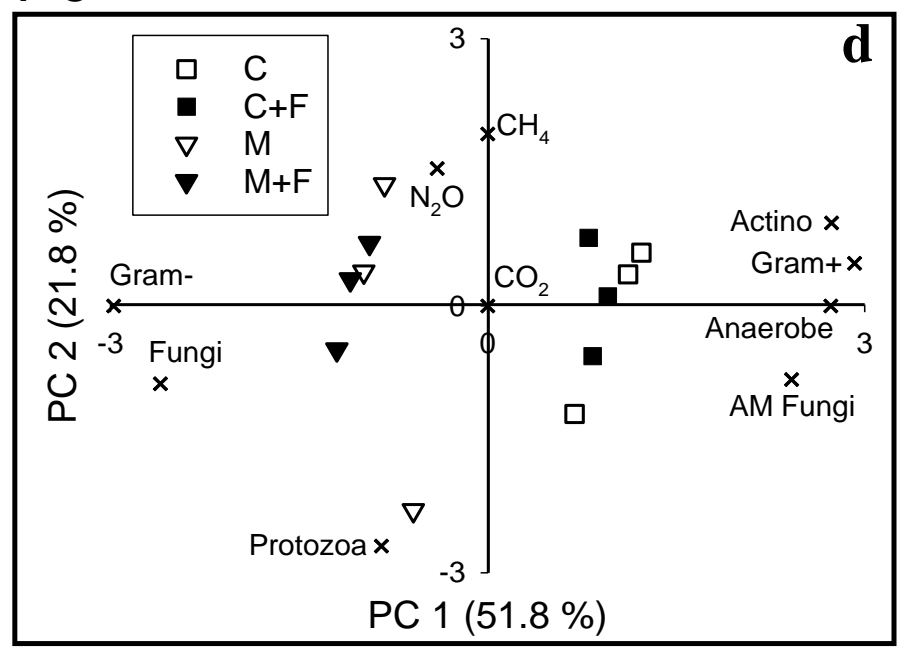

\section{After soil recovery}

$6{ }^{\circ} \mathrm{C}$

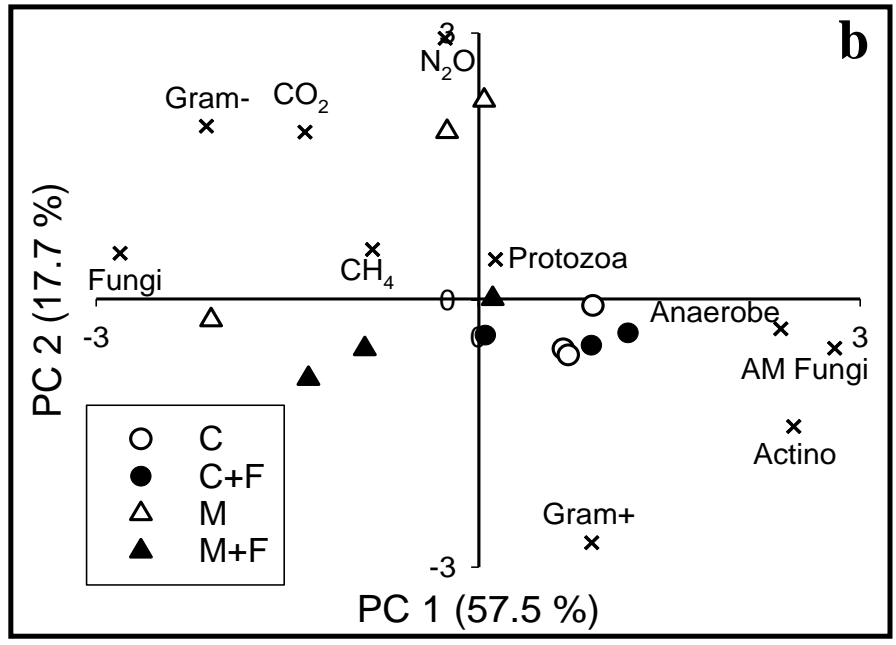

PC $1(57.5 \%)$

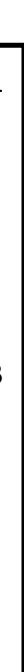

\section{Figure 5}




\section{Saline water}

\section{After flood stage}

$6{ }^{\circ} \mathrm{C}$

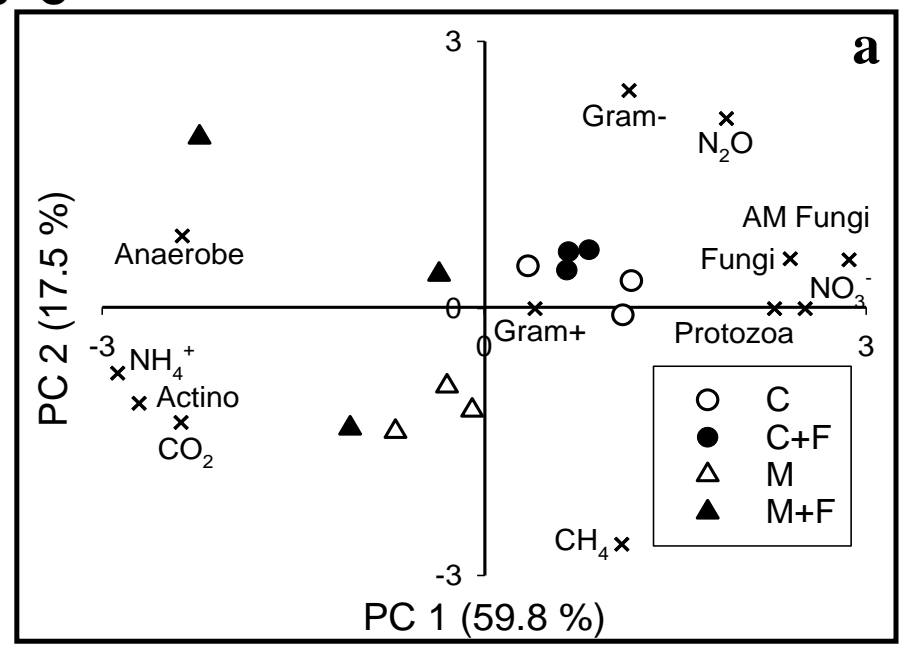

$14{ }^{\circ} \mathrm{C}$

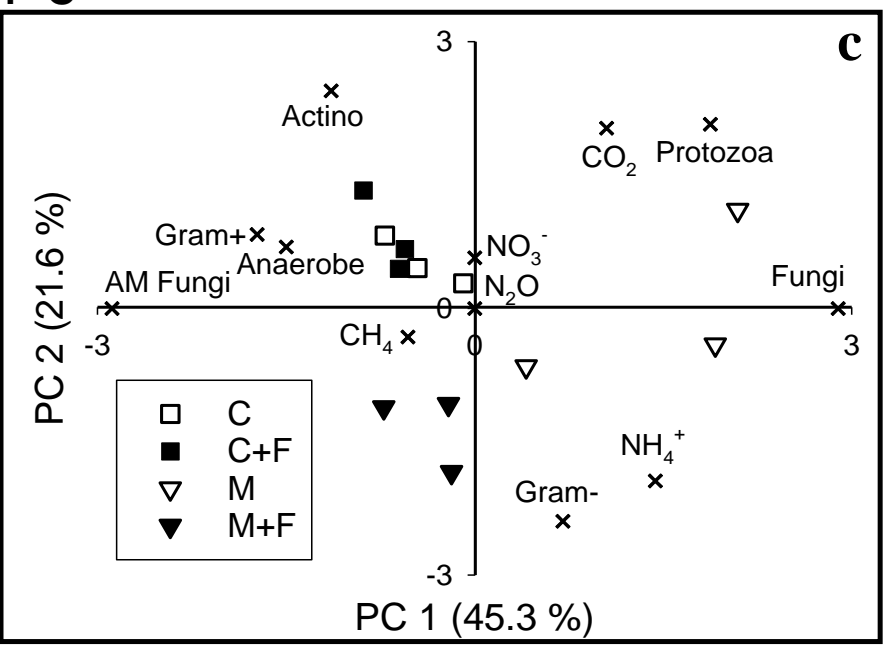

\section{Figure 6}

\section{After soil recovery}

$6^{\circ} \mathrm{C}$

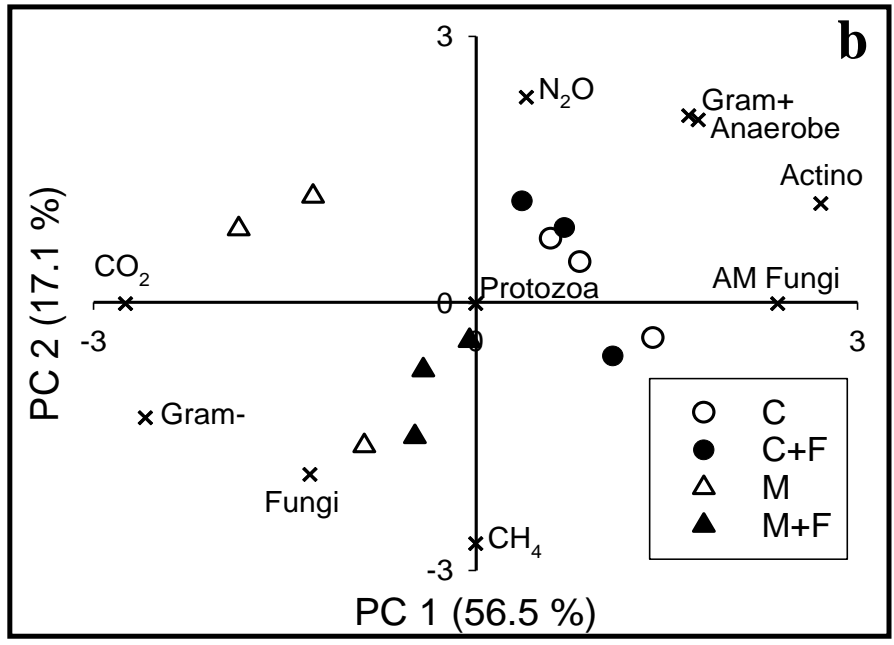

$14^{\circ} \mathrm{C}$

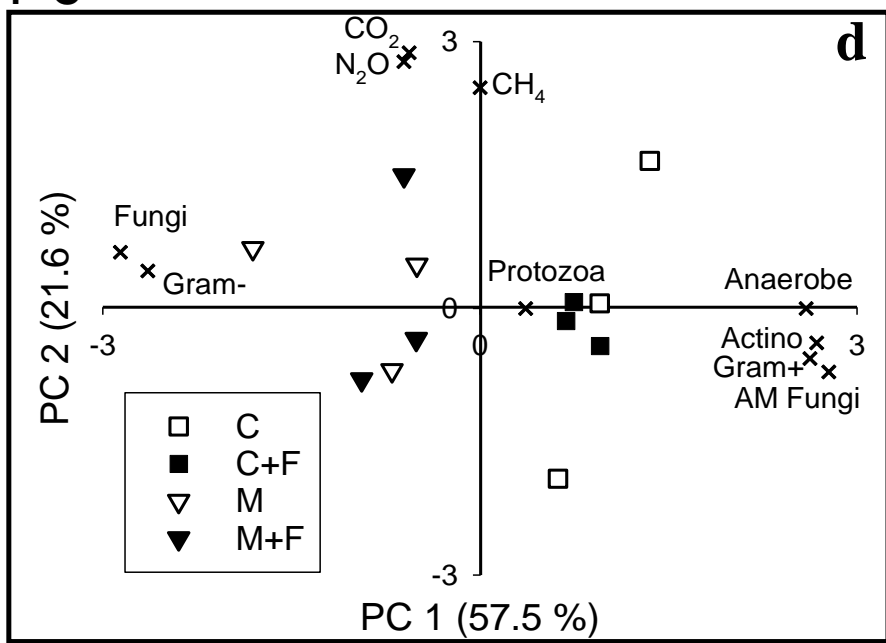




\section{Table 1}

Factorial analysis for flood water $\mathrm{pH}$ and EC (mean \pm standard error, $\mathrm{n}=6,12$ flooded recipients per type of flood water) as a function of the temperature and manure addition at day 1 and at the end of the flood stage (day 77) under the two different simulated conditions, freshwater and saline water. $P$ is the $P$ value for each factor and Treatment x Manure is the $P$ value of the interaction.

\begin{tabular}{|c|c|c|c|c|c|}
\hline \multirow[t]{2}{*}{ Factor } & \multicolumn{3}{|c|}{$\mathrm{pH}$} & \multicolumn{2}{|l|}{$\mathrm{EC}\left(\mathrm{mS} \mathrm{cm}^{-1}\right)$} \\
\hline & & Day 1 & Day 77 & Day 1 & Day 77 \\
\hline & & Freshwater & & & \\
\hline \multirow[t]{3}{*}{ Temperature } & $6^{\circ}$ & $7.30 \pm 0.20$ & $7.70 \pm 0.09$ & $0.18 \pm 0.06$ & $0.47 \pm 0.17$ \\
\hline & $14^{\circ}$ & $7.11 \pm 0.16$ & $7.85 \pm 0.09$ & $0.13 \pm 0.03$ & $0.39 \pm 0.12$ \\
\hline & & 0.359 & 0.146 & 0.060 & $<0.001$ \\
\hline \multirow{7}{*}{ Manure } & $\mathrm{C}$ & $7.08 \pm 0.19$ & $7.72 \pm 0.11$ & $0.05 \pm 0.01$ & $0.10 \pm 0.01$ \\
\hline & M & $7.33 \pm 0.16$ & $7.82 \pm 0.07$ & $0.25 \pm 0.03$ & $0.76 \pm 0.05$ \\
\hline & & 0.245 & 0.316 & $<0.001$ & $<0.001$ \\
\hline & $\mathrm{C} \times 6^{\circ}$ & $6.92 \pm 0.22$ & $7.51 \pm 0.05$ & & $0.08 \pm 0.01$ \\
\hline & $\mathrm{C} \times 14^{\circ}$ & $7.24 \pm 0.32$ & $7.94 \pm 0.11$ & & $0.12 \pm 0.01$ \\
\hline & $\mathrm{M} \times 6^{\circ}$ & $7.68 \pm 0.04$ & $7.89 \pm 0.04$ & & $0.86 \pm 0.03$ \\
\hline & $\mathrm{M} \times 14^{\circ}$ & $6.98 \pm 0.09$ & $7.76 \pm 0.14$ & & $0.66 \pm 0.01$ \\
\hline \multicolumn{2}{|l|}{ Temperature x Manure } & 0.035 & 0.016 & 0.090 & $<0.001$ \\
\hline \multirow{3}{*}{ Temperature } & & Saline water & & & \\
\hline & $6^{\circ}$ & $7.42 \pm 0.04$ & $7.43 \pm 0.18$ & $25.80 \pm 1.50$ & $30.78 \pm 1.10$ \\
\hline & $14^{\circ}$ & $7.41 \pm 0.02$ & $7.54 \pm 0.26$ & $27.52 \pm 0.40$ & $28.80 \pm 0.35$ \\
\hline$P$ & & 0.669 & 0.148 & 0.226 & 0.002 \\
\hline \multirow[t]{7}{*}{ Manure } & $\mathrm{C}$ & $7.36 \pm 0.03$ & $7.00 \pm 0.06$ & $28.00 \pm 0.13$ & $30.78 \pm 1.10$ \\
\hline & M & $7.47 \pm 0.02$ & $7.97 \pm 0.07$ & $25.32 \pm 1.40$ & $28.80 \pm 0.34$ \\
\hline & & 0.009 & $<0.001$ & 0.074 & 0.002 \\
\hline & $\mathrm{C} \times 6^{\circ}$ & & $7.04 \pm 0.12$ & & $33.17 \pm 0.52$ \\
\hline & $\mathrm{C} \times 14^{\circ}$ & & $6.97 \pm 0.05$ & & $28.40 \pm 0.32$ \\
\hline & $\mathrm{M} \times 6^{\circ}$ & & $7.82 \pm 0.03$ & & $28.40 \pm 0.23$ \\
\hline & $\mathrm{M} \times 14^{\circ}$ & & $8.12 \pm 0.06$ & & $29.20 \pm 0.60$ \\
\hline Temperature x Manure & & 0.187 & 0.032 & 0.210 & $<0.001$ \\
\hline
\end{tabular}

C: control without manure; M: broiler litter application $\left(9.1\right.$ ton ha $\left.^{-1}\right)$. 


\section{Table 2}

Factorial analysis of potential losses of nutrients (mean \pm standard error, $\mathrm{n}=6,12$ flooded recipients per kind of water) as a function of the temperature and manure addition at the end of the experiment under the two different simulated conditions of flooding, freshwater and saline water. $P$ is the $P$ value for each factor and Treatment $\mathrm{x}$ Manure is the $P$ value of the interaction.

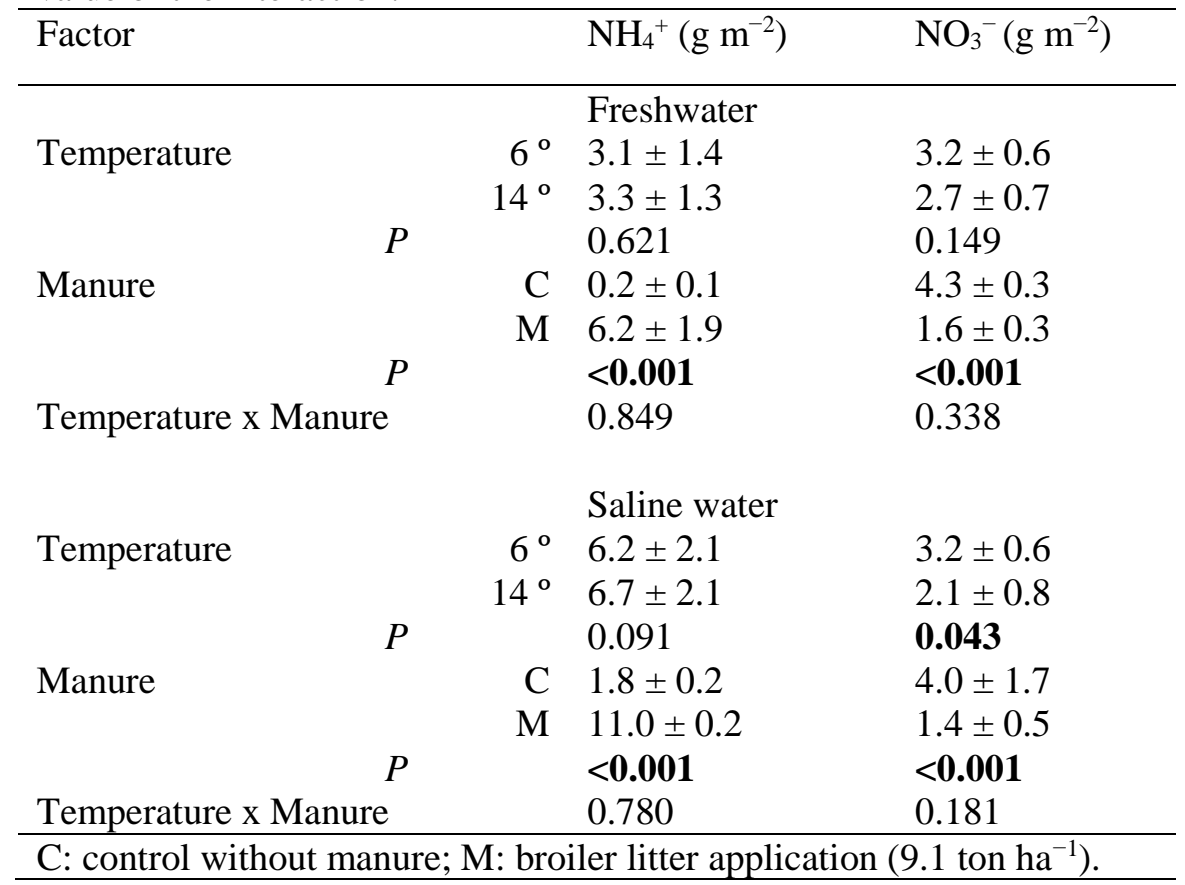


Table 3

Factorial analysis for cumulative GHG fluxes and total global warming potential (GWP, expressed in $\mathrm{g}$ of $\mathrm{CO}_{2}$ equivalents; mean \pm standard error, $\mathrm{n}=12,24$ recipients per type of flood water) at the end of the experiment as a function of flood, temperature and manure under the two different simulated conditions, freshwater and saline water. $P$ is the $P$ value for each factor and the $P$ values for the combination of factors is shown after Interactions $(P)$.

\begin{tabular}{|c|c|c|c|c|c|}
\hline Factor & & $\begin{array}{l}\mathrm{CH}_{4} \\
\mathrm{~g} \mathrm{C} \mathrm{m}^{-2}\end{array}$ & $\begin{array}{l}\mathrm{CO}_{2} \\
\mathrm{~g} \mathrm{C} \mathrm{m}^{-2}\end{array}$ & $\begin{array}{l}\mathrm{N}_{2} \mathrm{O} \\
\mathrm{g} \mathrm{N} \mathrm{m}^{-2}\end{array}$ & 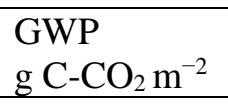 \\
\hline & & Freshwater & & & \\
\hline \multirow[t]{2}{*}{ Flood } & Non flood & $1.2 \pm 0.9$ & $53.8 \pm 10.5$ & $0.25 \pm 0.08$ & $167.7 \pm 53.0$ \\
\hline & Flood & $9.4 \pm 5.4$ & $35.5 \pm 11.6$ & $0.11 \pm 0.04$ & $367.2 \pm 192.2$ \\
\hline$P$ & & 0.011 & 0.002 & 0.001 & 0.048 \\
\hline \multirow{3}{*}{ Temperature } & $6^{\circ}$ & $0.02 \pm 0.02$ & $22.8 \pm 7.4$ & $0.06 \pm 0.02$ & $41.3 \pm 13.2$ \\
\hline & $14^{\circ}$ & $10.5 \pm 4.7$ & $66.5 \pm 11.0$ & $0.30 \pm 0.07$ & $493.6 \pm 179.2$ \\
\hline & & 0.002 & $<0.001$ & $<0.001$ & $<0.001$ \\
\hline \multirow[t]{2}{*}{ Manure } & $\mathrm{C}$ & $0.01 \pm 0.02$ & $18.4 \pm 5.8$ & $0.08 \pm 0.02$ & $42.3 \pm 10.6$ \\
\hline & M & $10.6 \pm 5.3$ & $70.9 \pm 10.1$ & $0.28 \pm 0.08$ & $492.7 \pm 179.6$ \\
\hline$P$ & & 0.002 & $<0.001$ & $<0.001$ & $<0.001$ \\
\hline \multicolumn{6}{|l|}{ Interactions $(P)$} \\
\hline \multicolumn{2}{|l|}{ Flood x Temperature } & 0.011 & 0.211 & 0.488 & 0.013 \\
\hline Flood x Manure & & 0.011 & 0.858 & 0.002 & 0.033 \\
\hline \multicolumn{2}{|l|}{ Temperature x Manure } & 0.002 & 0.016 & $<0.001$ & $<0.001$ \\
\hline \multicolumn{2}{|l|}{3 factors } & 0.012 & 0.812 & 0.031 & 0.023 \\
\hline \multirow{3}{*}{ Flood } & & Saline water & & & \\
\hline & Non flood & $0.39 \pm 0.30$ & $50.0 \pm 6.1$ & $0.47 \pm 0.06$ & $201.6 \pm 17.6$ \\
\hline & Flood & $0.26 \pm 0.14$ & $20.7 \pm 7.1$ & $0.15 \pm 0.03$ & $72.3 \pm 10.6$ \\
\hline$P$ & & 0.542 & $<0.001$ & $<0.001$ & $<0.001$ \\
\hline \multirow[t]{2}{*}{ Temperature } & $6^{\circ}$ & $0.03 \pm 0.02$ & $22.6 \pm 7.7$ & $0.25 \pm 0.06$ & $97.8 \pm 18.9$ \\
\hline & $14^{\circ}$ & $0.62 \pm 0.26$ & $48.0 \pm 10.3$ & $0.36 \pm 0.07$ & $176.1 \pm 23.4$ \\
\hline \multirow{3}{*}{ Manure } & & 0.012 & $<0.001$ & $<0.001$ & $<0.001$ \\
\hline & $\mathrm{C}$ & $0.02 \pm 0.02$ & $12.1 \pm 4.1$ & $0.43 \pm 0.07$ & $142.1 \pm 23.9$ \\
\hline & M & $0.63 \pm 0.26$ & $58.5 \pm 8.9$ & $0.18 \pm 0.04$ & $131.8 \pm 24.6$ \\
\hline$P$ & & 0.010 & $<0.001$ & $<0.001$ & 0.324 \\
\hline \multicolumn{6}{|l|}{ Interactions $(P)$} \\
\hline Flood $\mathrm{x}$ Temperature & & 0.325 & 0.820 & 0.407 & 0.167 \\
\hline Flood x Manure & & 0.484 & 0.008 & $<0.001$ & 0.187 \\
\hline Temperature x Manure & & 0.021 & 0.160 & 0.723 & 0.017 \\
\hline 3 factors & & 0.374 & 0.991 & 0.272 & 0.156 \\
\hline
\end{tabular}


Table 4

Factorial analysis of the total amount of PLFAs and taxonomic groups (mean \pm standard error, $\mathrm{n}=12,24$ recipients per type of flood water) after the flood and soil recovery stages for freshwater treatments. $P$ is the $P$ value for each factor and the $P$ values for the combination of factors is shown after Interactions

\begin{tabular}{|c|c|c|c|c|c|c|c|c|c|}
\hline Factor & & $\begin{array}{l}\text { PLFA } \\
\left(\mathrm{nmol} \mathrm{g}^{-1}\right)\end{array}$ & $\begin{array}{l}\text { Gram+ } \\
(\%)\end{array}$ & $\begin{array}{l}\text { Gram- }^{-} \\
(\%)\end{array}$ & $\begin{array}{l}\text { Actinomycetes } \\
(\%)\end{array}$ & $\begin{array}{l}\text { Anaerobe } \\
(\%)\end{array}$ & $\begin{array}{l}\text { AM Fungi } \\
(\%)\end{array}$ & $\begin{array}{l}\text { Protozoa } \\
(\%)\end{array}$ & $\begin{array}{l}\text { Fungi } \\
(\%)\end{array}$ \\
\hline & & After flood stage & & & & & & & \\
\hline \multirow{2}{*}{ Flood } & Non flood & $224.5 \pm 8.2$ & $26.5 \pm 0.3$ & $48.1 \pm 0.7$ & $16.3 \pm 0.50$ & $1.45 \pm 0.08$ & $4.44 \pm 0.12$ & $2.27 \pm 0.17$ & $1.00 \pm 0.13$ \\
\hline & Flood & $169.3 \pm 9.3$ & $26.7 \pm 0.3$ & $47.4 \pm 0.5$ & $16.6 \pm 0.3$ & $1.61 \pm 0.08$ & $4.44 \pm 0.10$ & $2.30 \pm 0.16$ & $0.91 \pm 0.15$ \\
\hline$P$ & & $<0.001$ & 0.415 & 0.051 & 0.016 & 0.167 & 0.966 & 0.887 & 0.433 \\
\hline \multirow[t]{2}{*}{ Temperature } & $6^{\circ}$ & $214.0 \pm 12.9$ & $26.8 \pm 0.3$ & $47.2 \pm 0.5$ & $16.6 \pm 0.4$ & $1.53 \pm 0.08$ & $4.49 \pm 0.13$ & $2.28 \pm 0.17$ & $1.14 \pm 0.17$ \\
\hline & $14^{\circ}$ & $180.0 \pm 8.5$ & $26.4 \pm 0.4$ & $48.3 \pm 0.7$ & $16.3 \pm 0.43$ & $1.54 \pm 0.09$ & $4.39 \pm 0.08$ & $2.28 \pm 0.16$ & $0.77 \pm 0.07$ \\
\hline$P$ & & $<0.001$ & 0.182 & 0.005 & 0.085 & 0.890 & 0.058 & 0.980 & 0.005 \\
\hline \multirow[t]{2}{*}{ Manure } & $\mathrm{C}$ & $181.1 \pm 12.7$ & $27.1 \pm 0.2$ & $46.1 \pm 0.1$ & $17.8 \pm 0.1$ & $1.59 \pm 0.06$ & $4.75 \pm 0.06$ & $2.13 \pm 0.08$ & $0.63 \pm 0.02$ \\
\hline & M & $212.7 \pm 9.3$ & $26.1 \pm 0.4$ & $49.4 \pm 0.5$ & $15.1 \pm 0.2$ & $1.47 \pm 0.10$ & $4.13 \pm 0.04$ & $2.43 \pm 0.21$ & $1.28 \pm 0.14$ \\
\hline$P$ & & $<0.001$ & 0.005 & $<0.001$ & $<0.001$ & 0.299 & $<0.001$ & 0.169 & $<0.001$ \\
\hline \multicolumn{10}{|l|}{ Interactions $(P)$} \\
\hline Flood $\mathrm{x}$ Temperature & & 0.113 & 0.899 & 0.084 & 0.116 & 0.022 & 0.004 & 0.086 & 0.444 \\
\hline Flood x Manure & & 0.003 & 0.249 & 0.013 & $<0.001$ & 0.434 & 0.032 & 0.768 & 0.329 \\
\hline Temperature x Manure & & 0.409 & $<0.001$ & $<0.001$ & 0.815 & 0.334 & 0.002 & 0.278 & 0.017 \\
\hline \multirow[t]{2}{*}{3 factors } & & 0.620 & 0.221 & 0.423 & 0.013 & 0.655 & 0.011 & 0.067 & 0.679 \\
\hline & & After soil recovery & & & & & & & \\
\hline \multirow[t]{2}{*}{ Flood } & Non flood & $139.6 \pm 3.9$ & $25.4 \pm 0.4$ & $48.4 \pm 0.8$ & $16.8 \pm 0.4$ & $1.41 \pm 0.07$ & $4.62 \pm 0.09$ & $2.26 \pm 0.13$ & $1.04 \pm 0.08$ \\
\hline & Flood & $131.8 \pm 2.5$ & $25.8 \pm 0.3$ & $48.0 \pm 0.6$ & $17.1 \pm 0.3$ & $1.49 \pm 0.07$ & $4.39 \pm 0.11$ & $2.23 \pm 0.10$ & $1.03 \pm 0.09$ \\
\hline $\mathrm{P}$ & & 0.015 & 0.028 & $<0.001$ & 0.109 & 0.154 & 0.001 & 0.837 & 0.892 \\
\hline \multirow[t]{2}{*}{ Temperature } & $6^{\circ}$ & $143.3 \pm 3.3$ & $25.9 \pm 0.3$ & $48.3 \pm 0.7$ & $16.6 \pm 0.4$ & $1.56 \pm 0.04$ & $4.51 \pm 0.10$ & $2.12 \pm 0.09$ & $0.99 \pm 0.10$ \\
\hline & $14^{\circ}$ & $128.0 \pm 1.7$ & $25.4 \pm 0.4$ & $48.1 \pm 0.7$ & $17.3 \pm 0.3$ & $1.34 \pm 0.07$ & $4.49 \pm 0.11$ & $2.37 \pm 0.12$ & $1.07 \pm 0.08$ \\
\hline $\mathrm{P}$ & & $<0.001$ & 0.003 & 0.027 & $<0.001$ & $<0.001$ & 0.735 & 0.158 & 0.311 \\
\hline \multirow[t]{2}{*}{ Manure } & $\mathrm{C}$ & $132.2 \pm 3.1$ & $26.6 \pm 0.1$ & $46.0 \pm 0.1$ & $18.1 \pm 0.1$ & $1.59 \pm 0.03$ & $4.78 \pm 0.03$ & $2.22 \pm 0.09$ & $0.79 \pm 0.05$ \\
\hline & M & $139.1 \pm 3.6$ & $24.7 \pm 0.3$ & $50.4 \pm 0.3$ & $15.8 \pm 0.2$ & $1.31 \pm 0.07$ & $4.22 \pm 0.08$ & $2.27 \pm 0.13$ & $1.27 \pm 0.05$ \\
\hline $\mathrm{P}$ & & 0.027 & $<0.001$ & $<0.001$ & $<0.001$ & $<0.001$ & $<0.001$ & 0.734 & $<0.001$ \\
\hline \multicolumn{10}{|l|}{ Interactions $(\mathrm{P})$} \\
\hline Flood $\mathrm{x}$ Temperature & & 0.049 & 0.004 & $<0.001$ & 0.349 & 0.563 & 0.005 & 0.549 & 0.460 \\
\hline Flood x Manure & & 0.384 & 0.009 & $<0.001$ & 0.100 & 0.692 & 0.356 & 0.486 & 0.541 \\
\hline Temperature x Manure & & 0.439 & $<0.001$ & $<0.001$ & 0.002 & 0.007 & 0.869 & 0.232 & 0.335 \\
\hline 3 factors & & 0.164 & 0.005 & $<0.001$ & 0.676 & 0.446 & 0.040 & 0.445 & 0.985 \\
\hline
\end{tabular}


Table 5

Factorial analysis of the total amount of PLFAs and taxonomic groups (mean \pm standard error, $\mathrm{n}=12,24$ recipients per type of flood water) after the flooding and recovery stages for saline water treatments. $P$ is the $P$ value for each factor and the $P$ values for the combination of factors is shown after Interactions $(P)$.

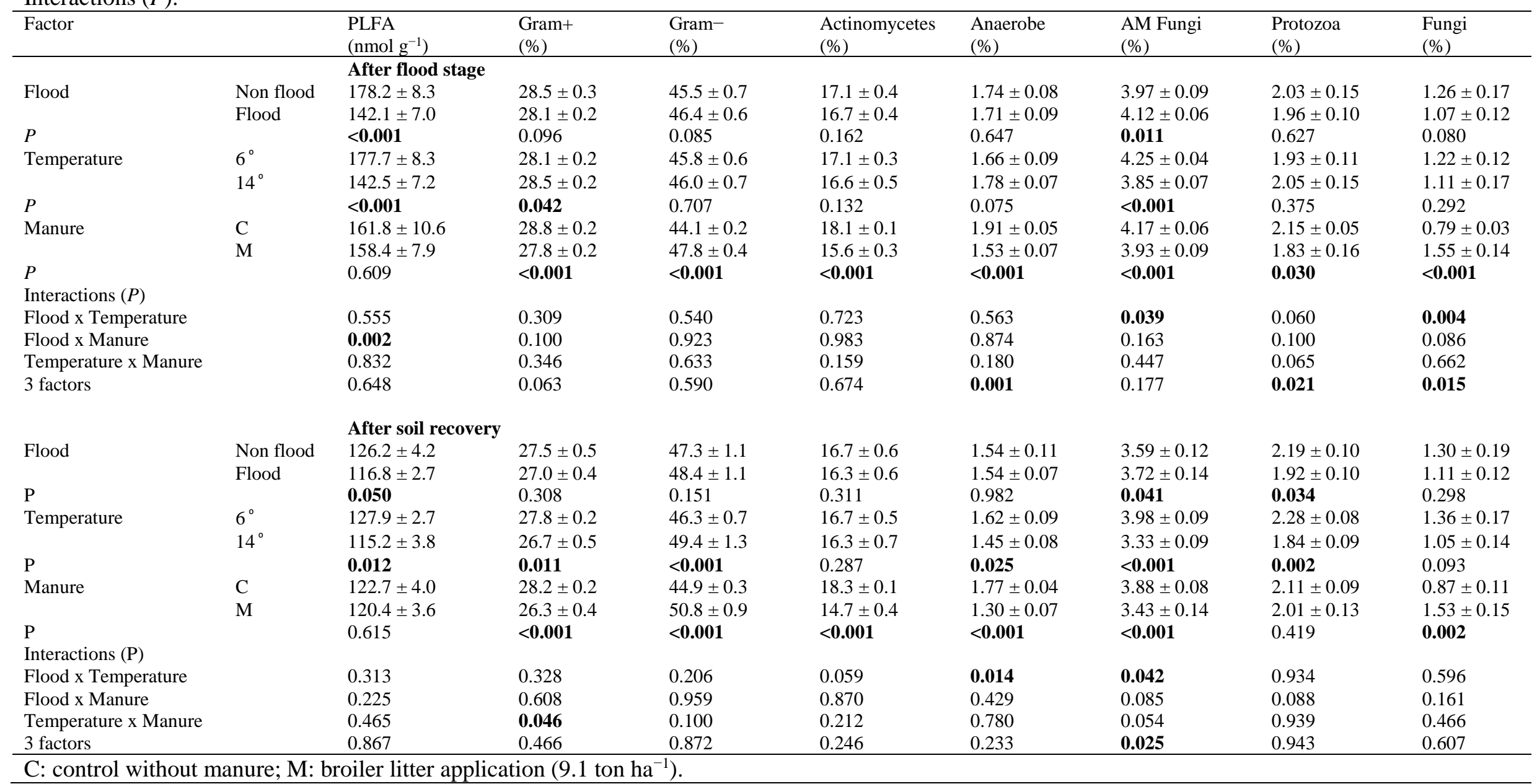



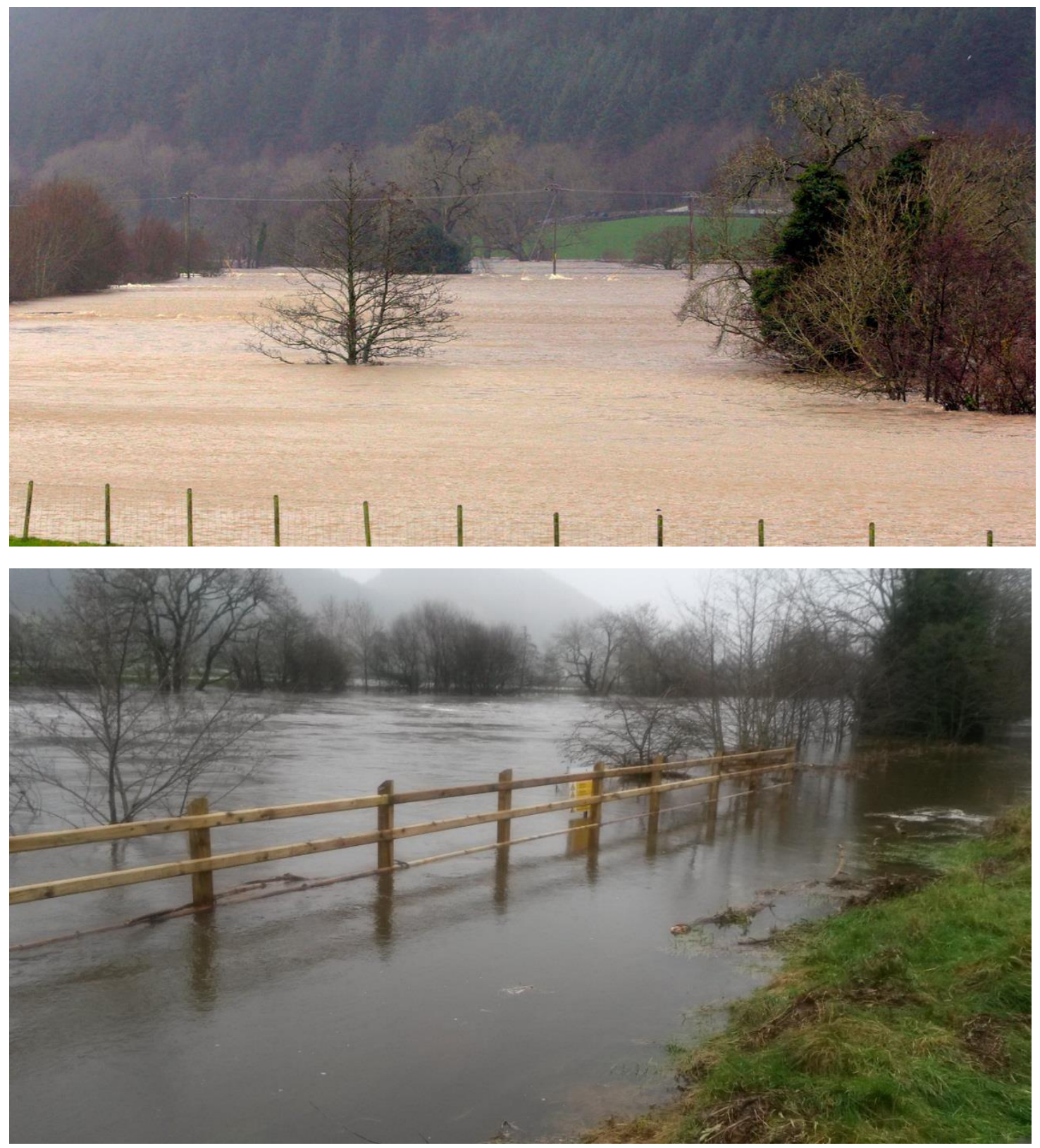

Fig. A.1. Recent riverine flooding of agricultural fields within the local region of this study. 


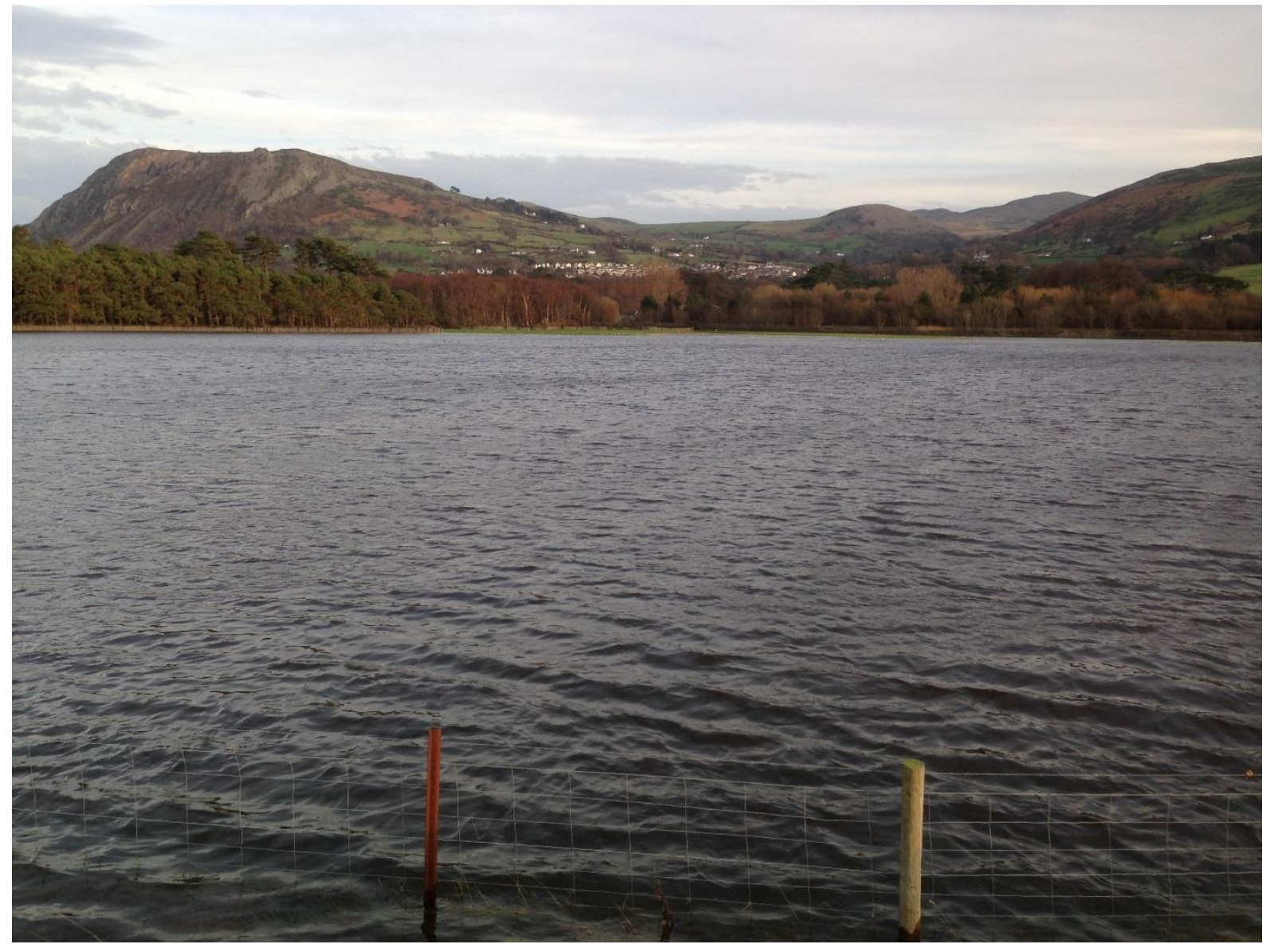

Fig. A.2. Recent coastal flooding of low lying agricultural fields within the local region of this study. 


\section{Table A.1}

Fatty acids ( $>0.5 \%$ of the total PLFAs) considered in the study as biomarkers for the different taxonomic groups.

\section{Biomarker}

14:0 ISO, 14:0 anteiso, 15:0 ISO, 15:0 anteiso , 15:1 iso w6c, 16:0 iso , 17:0 iso , 17:0 anteiso , 17:1 iso

Taxonomic group

References

w9c, 18:0 iso

16:1w6c, 16:1w7c, 16:1w9c, 17:1w8c, 17:0 cyclo w7c, Prokaryotes: Gram- bacteria

18:1w5c, 18:1 w9c, 18:1w7c, 19:0 cyclo w7c

16:0 10 methyl, 17:0 10 methyl, 17:1w7c 10 methyl, Prokaryotes: actinomycetes, Gram+ bacteria

18:0 10 methyl, 18:1w7c 10 methyl

15:0 DMA

$20: 4 w 6$

$18: 2 w 6 c$

$16: 1 w 5 c, 20: 1 w 9 c$

$15: 0,16: 0,17: 0,18: 0,20: 0,22: 0$
Prokaryotes: Anaerobic bacteria

Prokaryotes: Gram+ bacteria

Ratledge and Wilkinson (1988), Kieft et al. (1994),

Paul and Clark (1996), Zelles (1999), Olsson et al.

(1999), Bartelt-Ryser et al. (2005)

Kieft et al. (1994), Paul and Clark (1996), Zelles (1999)

Zelles (1999)

Eukaryotes: protozoa

Paul and Clark (1996)

Eukaryotes: fungi

Paul and Clark (1996)

Eukaryotes: arbuscular mycorrhiza, fungi

Olson et al. (1999), Madan et al. (2002)

Not assigned to a taxonomic group 
Table A.2

Soil $(0-15 \mathrm{~cm})$ and floodwater properties (mean \pm standard error, $\mathrm{n}=4$ ).

\begin{tabular}{llll}
\hline Property & Soil & Freshwater & Saline water \\
& & & \\
\hline Particle size: sand/silt/clay $\left(\mathrm{g} \mathrm{kg}^{-1}\right)$ & $510 / 300 / 190$ & & \\
Organic matter $\left(\mathrm{g} \mathrm{kg}^{-1}\right)$ & $78 \pm 5$ & & \\
Total C $\left(\mathrm{g} \mathrm{kg}^{-1}\right)$ & $34 \pm 3$ & & \\
Total N $\left(\mathrm{g} \mathrm{kg}^{-1}\right)$ & $3.4 \pm 0.3$ & & \\
Extractable P $\left(\mathrm{mg} \mathrm{kg}^{-1}\right)$ & $38 \pm 4$ & & \\
Extractable K $\left(\mathrm{mg} \mathrm{kg}^{-1}\right)$ & $122 \pm 11$ & & \\
$\mathrm{pH}$ & $6.92 \pm 0.28$ & $6.45 \pm 0.05$ & $7.33 \pm 0.01$ \\
$\mathrm{EC}\left(\mathrm{mS} \mathrm{cm}^{-1}\right)$ & $0.10 \pm 0.03$ & $0.03 \pm 0.00$ & $29.33 \pm 0.03$ \\
$\mathrm{NH}_{4}^{+}\left(\mathrm{mg} \mathrm{l}^{-1}\right)$ & & $0.27 \pm 0.02$ & $3.42 \pm 0.18$ \\
$\mathrm{NO}_{3}^{-}\left(\mathrm{mg} \mathrm{l}^{-1}\right)$ & & $1.09 \pm 0.01$ & $1.06 \pm 0.02$ \\
$\mathrm{PO}_{4}^{-3}\left(\mathrm{mg} \mathrm{l}^{-1}\right)$ & & $0.07 \pm 0.01$ & $0.84 \pm 0.03$ \\
\hline
\end{tabular}


Table A.3

Manure properties (fresh weight basis,

mean \pm standard error, $n=3$ )

Property

\begin{tabular}{ll}
\hline Dry matter $\left(\mathrm{g} \mathrm{kg}^{-1}\right)$ & $483.7 \pm 0.9$
\end{tabular}

Total N $\left(\mathrm{g} \mathrm{kg}^{-1}\right) \quad 27.6 \pm 0.00$

Total C $\left(\mathrm{g} \mathrm{kg}^{-1}\right) \quad 211.7 \pm 0.7$

$\mathrm{C}: \mathrm{N}$

$8: 1$

$\mathrm{NO}_{3}{ }^{-}\left(\mathrm{mg} \mathrm{N} \mathrm{kg}^{-1}\right) \quad<10$

$\mathrm{NH}_{4}{ }^{+}\left(\mathrm{mg} \mathrm{N} \mathrm{kg}^{-1}\right) \quad 4105 \pm 63$

Uric acid-N $\left(\mathrm{g} \mathrm{kg}^{-1}\right) \quad 6.6 \pm 0.2$

Total P $\left(\mathrm{g} \mathrm{kg}^{-1}\right) \quad 8.2 \pm 0.1$

Total K $\left(\mathrm{g} \mathrm{kg}^{-1}\right) \quad 19.0 \pm 1.0$

$\mathrm{pH}(1: 6)$

$5.54 \pm 0.07$ 
Table A.4.A

Factorial analysis of PLFAs ratios (mean, $\mathrm{n}=12$ recipients, 3 replications per combination of factors) after flood stage and after soil recovery stage for freshwater treatments. $P$ is the $P$ value for each factor and the $P$ values for the combination of factors is shown after Interactions $(P)$.

\begin{tabular}{|c|c|c|c|c|c|c|c|c|}
\hline \multirow[t]{2}{*}{ Factor } & & Fungi/Bacteria & Predator/Prey & Gram+/Gram- & Sat/Unsat & Mono/Poly & $16 / 17$ cyclo & $18 / 19$ cyclo \\
\hline & & \multicolumn{7}{|c|}{$\begin{array}{l}\text { Freshwater } \\
\text { After flood stage }\end{array}$} \\
\hline \multirow[t]{2}{*}{ Flood } & Non flood & 0.075 & 0.031 & 0.888 & 0.846 & 16.26 & 3.17 & 2.08 \\
\hline & Flood & 0.074 & 0.032 & 0.911 & 0.853 & 16.71 & 3.02 & 2.05 \\
\hline$P$ & & 0.669 & 0.837 & 0.074 & 0.632 & 0.655 & 0.364 & 0.323 \\
\hline \multirow[t]{2}{*}{ Temperature } & $6{ }^{\circ} \mathrm{C}$ & 0.078 & 0.032 & 0.915 & 0.848 & 15.66 & 3.34 & 2.02 \\
\hline & $14{ }^{\circ} \mathrm{C}$ & 0.071 & 0.031 & 0.884 & 0.851 & 17.31 & 2.85 & 2.10 \\
\hline$P$ & & $<0.001$ & 0.867 & 0.002 & 0.777 & 0.117 & 0.008 & 0.037 \\
\hline \multirow[t]{2}{*}{ Manure } & $\mathrm{C}$ & 0.075 & 0.030 & 0.968 & 0.862 & 17.88 & 2.67 & 1.89 \\
\hline & M & 0.073 & 0.033 & 0.831 & 0.837 & 15.08 & 3.52 & 2.24 \\
\hline$P$ & & 0.178 & 0.318 & $<0.001$ & 0.063 & 0.013 & $<0.001$ & $<0.001$ \\
\hline \multicolumn{9}{|l|}{ Interactions $(P)$} \\
\hline Flood x Temperature & & 0.033 & 0.090 & 0.159 & 0.160 & 0.117 & 0.716 & 0.097 \\
\hline Flood x Manure & & 0.703 & 0.698 & 0.008 & 0.018 & 0.645 & 0.013 & 0.008 \\
\hline Temperature x Manure & & 0.324 & 0.313 & $<0.001$ & $<0.001$ & 0.919 & 0.149 & 0.001 \\
\hline \multirow[t]{2}{*}{3 factors } & & 0.465 & 0.079 & 0.703 & 0.298 & 0.155 & 0.734 & 0.943 \\
\hline & & After soil recove & & & & & & \\
\hline \multirow[t]{2}{*}{ Flood } & Non flood & 0.078 & 0.031 & 0.873 & 0.810 & 16.01 & 2.90 & 2.05 \\
\hline & Flood & 0.075 & 0.031 & 0.891 & 0.826 & 15.97 & 2.96 & 1.99 \\
\hline $\mathrm{P}$ & & 0.007 & 0.832 & 0.008 & 0.165 & 0.958 & 0.533 & 0.114 \\
\hline \multirow{2}{*}{ Temperature } & $6{ }^{\circ} \mathrm{C}$ & 0.076 & 0.029 & 0.877 & 0.791 & 16.99 & 3.49 & 2.14 \\
\hline & $14^{\circ} \mathrm{C}$ & 0.077 & 0.033 & 0.888 & 0.844 & 14.98 & 2.36 & 1.90 \\
\hline $\mathrm{P}$ & & 0.216 & 0.145 & 0.081 & $<0.001$ & 0.033 & $<0.001$ & $<0.001$ \\
\hline \multirow[t]{2}{*}{ Manure } & $\mathrm{C}$ & 0.079 & 0.031 & 0.970 & 0.849 & 16.58 & 2.69 & 1.89 \\
\hline & M & 0.075 & 0.031 & 0.797 & 0.787 & 15.40 & 3.16 & 2.15 \\
\hline $\mathrm{P}$ & & 0.002 & 0.864 & $<0.001$ & $<0.001$ & 0.190 & $<0.001$ & $<0.001$ \\
\hline \multicolumn{9}{|l|}{ Interactions $(\mathrm{P})$} \\
\hline Flood x Temperature & & 0.064 & 0.506 & $<0.001$ & 0.119 & 0.904 & 0.060 & 0.108 \\
\hline Flood x Manure & & 0.967 & 0.506 & $<0.001$ & 0.022 & 0.862 & 0.146 & 0.327 \\
\hline Temperature x Manure & & 0.731 & 0.217 & 0.012 & 0.003 & 0.816 & $<0.001$ & 0.970 \\
\hline 3 factors & & 0.119 & 0.451 & 0.024 & 0.165 & 0.471 & 0.782 & 0.304 \\
\hline
\end{tabular}

C: control without manure; M: broiler litter application $\left(9.1\right.$ ton $\left.^{-1} \mathrm{~h}^{-1}\right)$. 
Table A.4.B

Factorial analysis of PLFAs ratios (mean, $\mathrm{n}=12$ recipients, 3 replications per combination of factors) after flood stage and after soil recovery stage for

saline water treatments. $P$ is the $P$ value for each factor and the $P$ values for the combination of factors is shown after Interactions $(P)$.

\begin{tabular}{|c|c|c|c|c|c|c|c|c|}
\hline Factor & 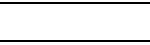 & Fungi/Bacteria & Predator/Prey & Gram+/Gram- & Sat/Unsat & Mono/Poly & 16/17 cyclo & 18/19cyclo \\
\hline & & $\begin{array}{l}\text { Saline water } \\
\text { After flood stage }\end{array}$ & & & & & & \\
\hline Flood & Non flood & 0.072 & 0.028 & 0.999 & 0.933 & 15.62 & 2.61 & 1.92 \\
\hline & Flood & 0.071 & 0.027 & 0.960 & 0.912 & 16.75 & 2.91 & 2.08 \\
\hline$P$ & & 0.422 & 0.571 & 0.050 & 0.031 & 0.126 & 0.025 & 0.008 \\
\hline Temperature & $6^{\circ} \mathrm{C}$ & 0.076 & 0.027 & 0.980 & 0.899 & 15.94 & 2.77 & 2.03 \\
\hline & $14^{\circ} \mathrm{C}$ & 0.068 & 0.028 & 0.980 & 0.946 & 16.42 & 2.75 & 1.98 \\
\hline$P$ & & $<0.001$ & 0.473 & 0.993 & $<0.001$ & 0.501 & 0.845 & 0.411 \\
\hline Manure & $\mathrm{C}$ & 0.070 & 0.030 & 1.058 & 0.949 & 16.23 & 2.42 & 1.87 \\
\hline & M & 0.074 & 0.025 & 0.902 & 0.896 & 16.14 & 3.10 & 2.13 \\
\hline$P$ & & 0.012 & 0.016 & $<0.001$ & $<0.001$ & 0.899 & $<0.001$ & $<0.002$ \\
\hline Interactions $(P)$ & & & & & & & & \\
\hline Flood x Temperature & & 0.030 & 0.071 & 0.739 & 0.353 & 0.003 & 0.968 & 0.387 \\
\hline Flood x Manure & & 0.221 & 0.116 & 0.505 & 0.032 & 0.017 & 0.740 & 0.125 \\
\hline Temperature x Manure & & 0.855 & 0.083 & 0.347 & 0.181 & 0.352 & 0.009 & 0.086 \\
\hline 3 factors & & 0.053 & 0.031 & 0.353 & 0.159 & 0.002 & 0.584 & 0.842 \\
\hline & & After soil recover & & & & & & \\
\hline Flood & Non flood & 0.067 & 0.030 & 0.937 & 0.906 & 14.88 & 2.74 & 1.94 \\
\hline & Flood & 0.066 & 0.026 & 0.899 & 0.891 & 17.02 & 2.98 & 2.07 \\
\hline $\mathrm{P}$ & & 0.553 & 0.033 & 0.158 & 0.255 & 0.043 & 0.176 & 0.140 \\
\hline Temperature & $6^{\circ} \mathrm{C}$ & 0.074 & 0.032 & 0.958 & 0.880 & 14.31 & 2.98 & 2.12 \\
\hline & $14^{\circ} \mathrm{C}$ & 0.059 & 0.025 & 0.878 & 0.917 & 17.59 & 2.74 & 1.89 \\
\hline $\mathrm{P}$ & & $<0.001$ & 0.001 & 0.006 & 0.012 & 0.004 & 0.197 & 0.014 \\
\hline Manure & $\mathrm{C}$ & 0.067 & 0.030 & 1.030 & 0.943 & 16.43 & 2.28 & 1.77 \\
\hline & M & 0.066 & 0.027 & 0.806 & 0.853 & 15.48 & 3.44 & 2.23 \\
\hline $\mathrm{P}$ & & 0.706 & 0.108 & $<0.001$ & $<0.001$ & 0.343 & $<0.001$ & $<0.001$ \\
\hline Interactions $(\mathrm{P})$ & & & & & & & & \\
\hline Flood x Temperature & & 0.712 & 0.886 & 0.123 & 0.226 & 0.868 & 0.134 & 0.120 \\
\hline Flood x Manure & & 0.377 & 0.111 & 0.715 & 0.559 & 0.096 & 0.843 & 0.583 \\
\hline Temperature $\mathrm{x}$ Manure & & 0.948 & 0.884 & 0.161 & 0.082 & 0.561 & 0.102 & 0.147 \\
\hline 3 factors & & 0.618 & 0.879 & 0.956 & 0.700 & 0.938 & 0.403 & 0.138 \\
\hline
\end{tabular}

